ECPS Leader Prof Ieseries \#1

August 2020

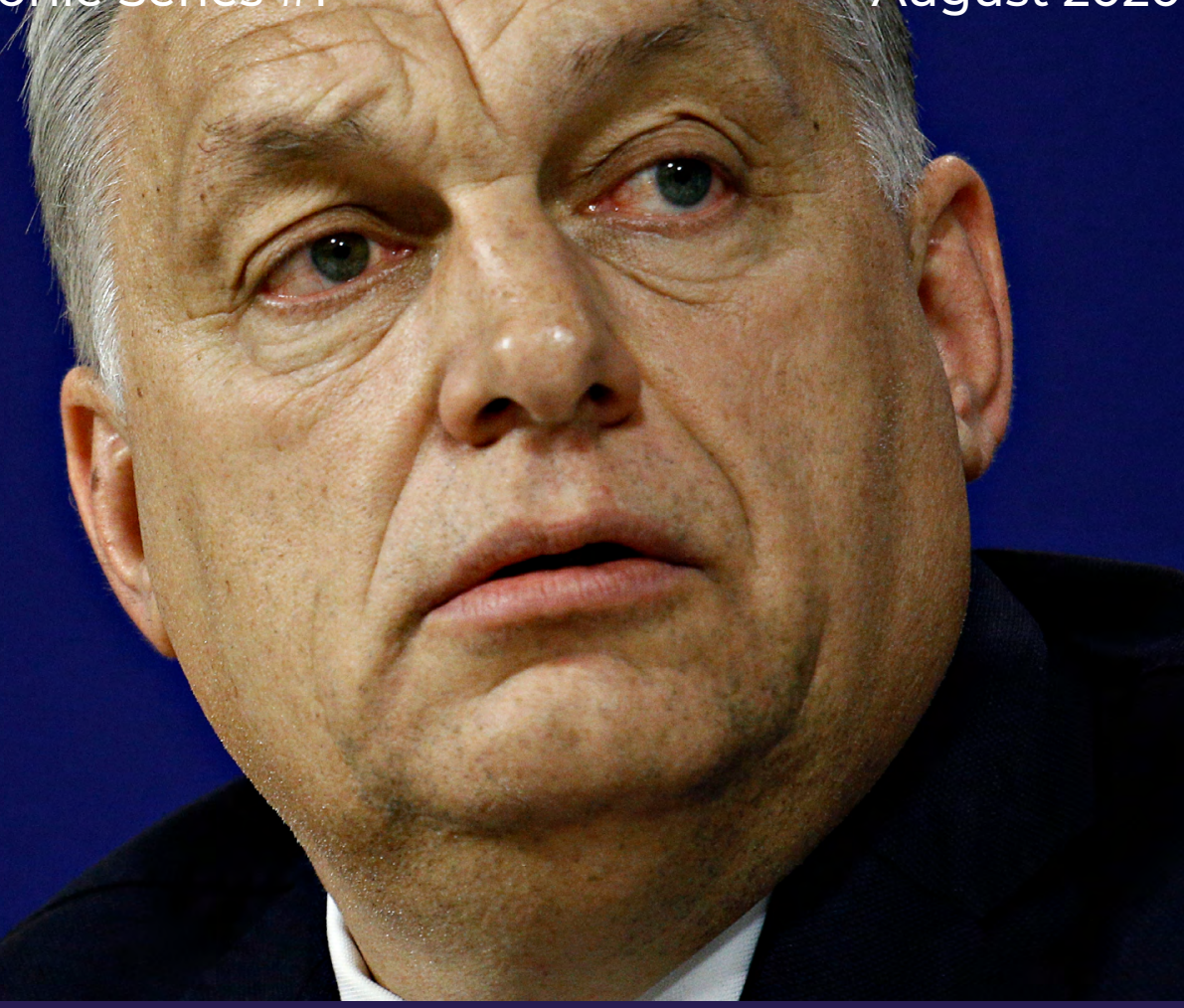

AUTHOR: Bulent Kenes

\title{
Viktor Orbán: Past to Present
}

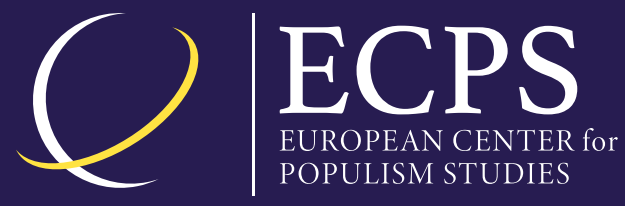




\section{Viktor Orbán: Past to Present \\ BY BULENT KENES}

\section{ABSTRACT}

Today, Hungary could be defined as, at best, an "illiberal democracy." Some even argue that the country is now a crude autocracy. Orbán is personally described as "irredentist," "right-wing populist," "authoritarian," "autocratic," and "Putinist." He's also been called a "strongman" and a "dictator." Orbán has outmaneuvered his opponents and tightened his clutch on power. He makes no secret of his plans to rule Hungary for the foreseeable future.

BULENT KENES is an academic and a journalist who has over 25 years of professional experience. He has managed multiple publications, both in Turkish and English.

ECPS Leader Profile Series offer analyses of political leaders and prominent public figures with populist tendencies. Unless otherwise indicated, the views expressed by the author are only attributable him and not to any institution with which they are associated.

The profile available for free downloading from the ECPS website (wWw. populismstudies.org)

(c) ECPS 2021 


\section{Table of contents}

1. INTRODUCTION.

5. LEGISLATIVE TSUNAMI \& INVASION OF PARTY APPARATCHIKS . 9

7. IMMIGRANTS: AN OPPORTUNITY TO CREATE A NEW ENEMY . . . . 13

8. A PROTOTYPE OF A POPULIST EUROSCEPTIC.

9. A "RUSSIAN TROJAN HORSE" INSIDE THE EU AND NATO?

10. FROM "CRONY CAPITALISM" TO "MAFIA STATE" 


\section{INTRODUCTION}

On June 16, 1989, over 200,000 Hungarians filled Heroes' Square in Budapest. They gathered for a memorial observance leading to the reburial of Imre Nagy, the leader of the failed 1956 Revolution. Nagy was a staunch Communist, but he had not lost his national pride; Hungarians had looked to him as a reformer capable of freeing them from the Stalinist grip of Matyas Rakosi. Nagy had been tried in secret, hanged on June 16, 1958, and buried in an unmarked grave (Congdon, 2018).

The mass gathering, which was a mix of ceremony and demonstration, was broadcast live on Hungarian television and ended with six speeches. The final speech was delivered by Viktor Mihály Orbán, a little-known 26-year old activist sporting a scruffy beard. He spoke for only seven minutes but electrified the crowd and the people watching at home (Lendvai, 2019). At the time, there were still 70,000 Soviet troops occupying Hungary; despite their presence, Orbán gave the most courageous speech of the gathering:

"Today, 33 years after the Hungarian Revolution and 31 years after the execution of the last responsible Hungarian prime minister, we have a chance to achieve by peaceful means everything that the '56 revolutionaries gained in a bloody battle, if only for a few days. If we believe in our own strength, we are capable of bringing the communist dictatorship to an end. If we are determined enough, we can compel the ruling party to submit to free elections. If we have not lost sight of the ideas of '56, we can vote for a government that will immediately enter into negotiations leading to the immediate beginning of Russian troop withdrawals," (Magyar Nemzet, 2014). 


\section{An Idealist or a Budding Opportunist?}

According to Paul Lendvai, Orbán, whose rhetoric so stirred Hungarians in 1989, was no idealist; he was, rather, a budding opportunist getting an early taste of power. Gabor Fodor, an Orbán rival who was once his close friend, observed that even as a young man, Viktor Orbán "was already possessed of those domineering, intolerant ways of thinking and behaving that are all too evident in him today." But, Fodor noted, "he was, in addition to all of this, sincere and likable." It is a combination of traits that suggests a certain ambivalence in Orbán's character, which perhaps helps explain the ease with which he transformed his political persona later in life (Lendvai, 2019).

Viktor Orbán was born in Szekesfehervar, in Hungary's Transdanubia region, but he grew up in the nearby villages of Alcsutdoboz and the somewhat larger Felcsut (Congdon, 2018). Initially, his family lived in the cramped house of his paternal grandparents. When Orbán was ten, as a consequence of arguments between his mother and grandmother, the family moved to a dilapidated house at the end of Felcsut's main street. The circumstances in which he grew up were orderly but very poor. Orbán has recalled how hard he and his siblings worked in the fields as young children: pulling beets, sorting potatoes, feeding the pigs and chickens. The house had no running water. Years later, Orbán described the "unforgettable experience" of using a bathroom for the first time, at age 15 and getting hot water by simply turning on a faucet (Lendvai, 2019).

The Orbán family's fortunes improved in the 1970s and 1980s, as his father earned a university degree and climbed the ranks of the ruling Socialist Workers' Party. Orbán was a bright student, and his parents sent him to a selective grammar school. But years later, he described himself in an interview as an "unbelievably bad child. Badly misbehaved, cheeky, violent. Not at all likable." He added: "At home, I had constant problems with discipline; my father beat me once or twice a year." Throughout his youth, his brief compulsory stint in the

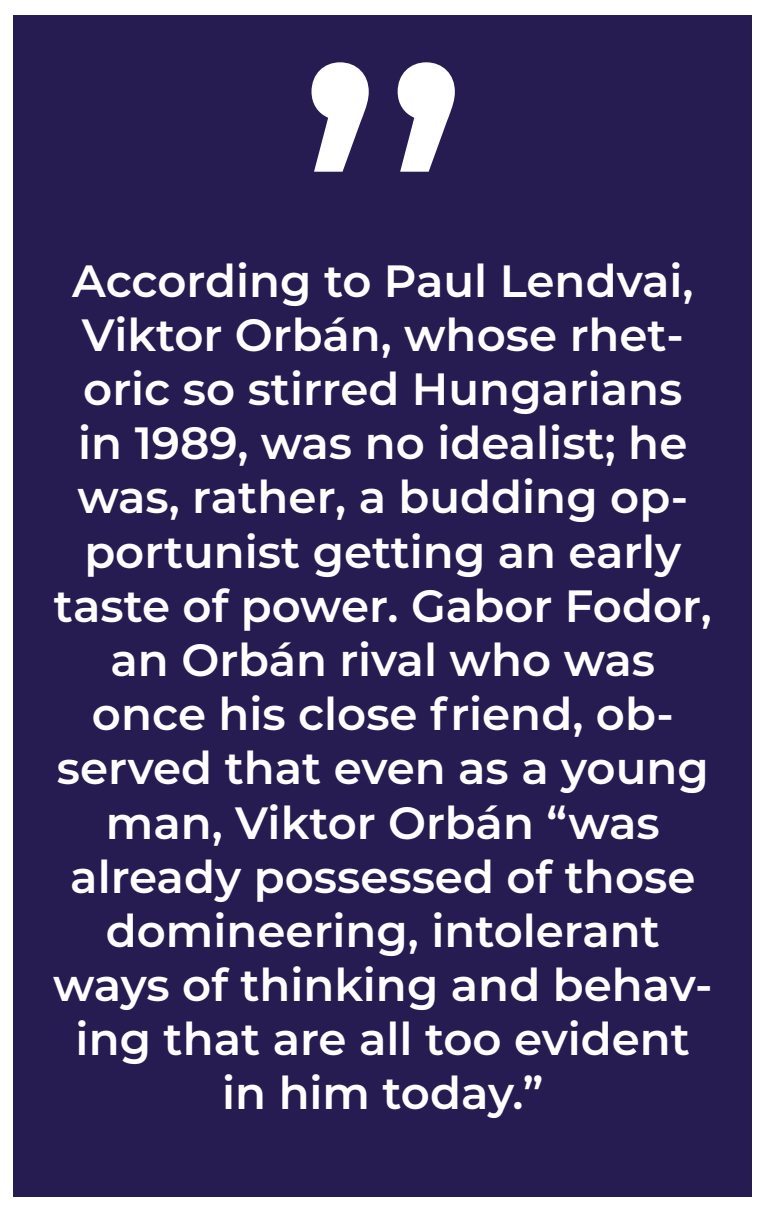

military, and his university years, his maxim remained unaltered: "If I'm hit once, then I hit back twice" (Lendvai, 2019).

After completing gymnasium studies in Szekesfehervar in 1981, he performed one year of military duty before enrolling as a law student at Eotvos Lorand (Budapest) University. He was among those who founded the Istvan Bibo Special College in 1983, where young scholars studied law and politics. One of the college's patrons was the Hungarian-born American investor and philanthropist Gyorgy (George) Soros, who also generously subsidized a student-run journal, language courses, and trips overseas. At the college, Orbán became part of a tightly knit group of liberals. He even found a part-time job in Soros's organization, which later became the Open Society Foundations (Lendvai, 2019 \& Congdon, 2018).

Orbán began to work for the Ministry of Food and Agriculture after completing his degree in 1987. On March 30, 1988, he and thirty-six other Bibo College fellows founded Fidesz (Fiatal Demokratak Szovetsege - Alliance of Young Democrats) as an in- 
dependent organization aimed at regime change. In 1989, three months after his famous speech at Nagy's reburial, Soros's foundation awarded Orbán a scholarship to study politics and conduct research on the idea of civil society in European political philosophy at Pembroke College, Oxford. At the time of his arrival in England, Margaret Thatcher, the uncompromising "Iron Lady," was prime minister - and a role model for the young Hungarian (Lendvai, 2019 \& Congdon, 2018).

\section{A Long and Bumpy Political Journey Begins}

In October 1989, Orbán took part in the Fidesz congress that voted to transform the youth organization into a political party, allowing it to participate in the free elections scheduled for the following spring. Although his scholarship was good for nine months, he, his wife Aniko Levai, and their four-month-old daughter permanently returned to Budapest in January 1990. In the April elections, Fidesz won 22 of 386 seats in parliament, while the Magyar Szocialista Part (the Socialist Party, the successor to the Communist Party) took 33. The conservative Magyar Demokrata Forum captured 165 seats and formed Hungary's first freely elected government under Jozsef Antall, a man of character who had eked out a living as a librarian and editor after playing an active role in the 1956 Revolution (Congdon, 2018).

In opposition, Fidesz remained true to its youthful image: Orbán and other politicians in the party kept their beards, long hair, jeans, and open-neck shirts. They advocated liberal reforms and were quick to condemn nationalist and antisemitic undercurrents in the governing coalition. Orbán himself scoffed at the populist rhetoric of the ruling parties, whose leaders "reject criticism of government policy by suggesting the opposition or media are undermining the standing of Hungary, are attacking the Hungarian nation itself," he said. This was a fair description of some elements in the Antall government and a

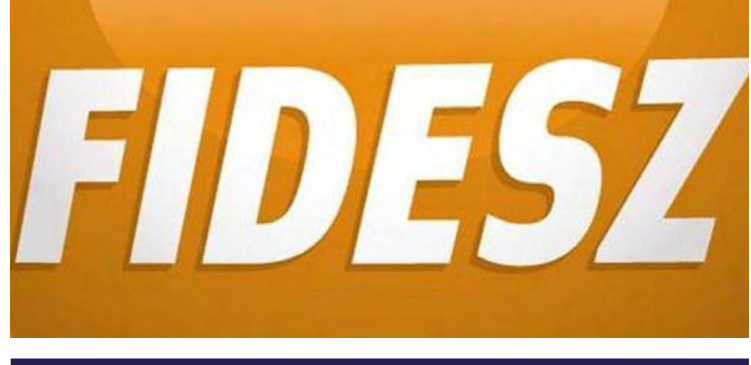

prescient foreshadowing of the populist style that Orbán himself would later adopt (Lendvai, 2019).

Lendvai wrote that despite their avowed liberalism, Orbán and his Fidesz circle had an uneasy relationship with an older generation of liberals, especially those of the Alliance of Free Democrats, many of whom were academics from bourgeois (and often Jewish) families. They were well-read, open to the world, and fluent in foreign languages - a stark contrast to the Fidesz leaders, who were mostly lawyers from rural areas or small towns. Orbán and his friends initially admired the older liberals but soon came to see them as overweening.

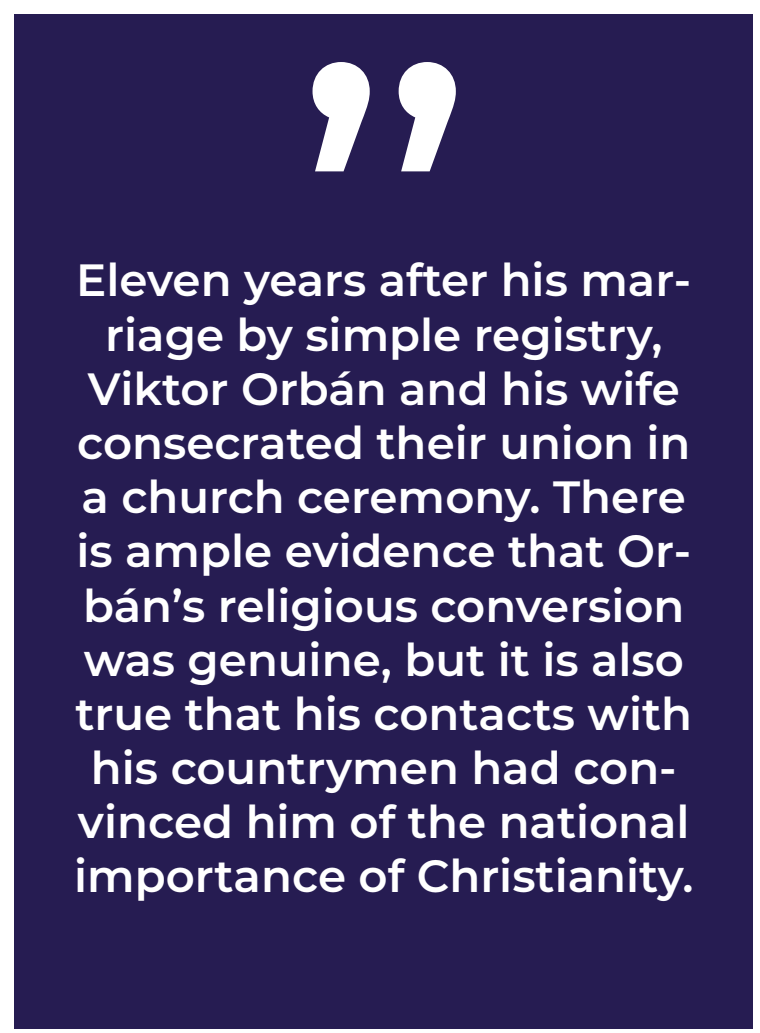


In 1991, a poll showed that Orbán, who was not yet 30, was the third most popular politician in Hungary. Two years later, he became the president of Fidesz. However, in the 1994 elections, the party suffered a crushing defeat. The former communists of the Hungarian Socialist Party quintupled the number of votes they had received in the prior election and formed a coalition with the Free Democrats; together, the two parties held over 72 percent of the seats in Parliament. In contrast, Fidesz had become the smallest party in Parliament, with only 20 seats. Seeing no other path to political survival, Orbán committed himself and the party to a rightward political shift. The erstwhile rebels of Fidesz began dressing conservatively and styling their hair neatly. Their speeches were now peppered with professions of faith in the nation, in Magyar tradition, in the homeland, in national interests, in respectability, in middle-class values, in the family, and in the love of the mother country (Lendvai, 2019).

"This was the first major step in Orbán's decades-long transformation into an autocratic right-wing populist. There seemed to be no deep ideological soul-searching involved - just clear-eyed calculations about what it would require to win power," wrote Lendvai (Lendvai, 2019). Orbán even changed his party's name to Fidesz - Magyar Polgari Part, or "Fidesz, the Hungarian Civic Party," in April 1995. Furthermore, two years later, and eleven years after his marriage by a simple registry, he and his wife consecrated their union in a church ceremony. There is ample evidence that Orbán's religious conversion was genuine, but it is also true that his contacts with his countrymen had convinced him of the national importance of Christianity (Congdon, 2018).

Meanwhile, the Socialist-Free Democrat government struggled under the weight of an unpopular package of economic reforms and a corruption scandal. In the elections of 1998, Fidesz triumphed with 29.48 percent of the vote, which assured the party 148 seats in Parliament. Orbán became prime minister. As the youngest prime minister in Hungarian history, Orbán led Hungary into NATO (1999) and moved Fidesz from the Liberal International bloc in European politics to the center-right European People's Party (EPP), founded in 1976 by several Christian Democratic parties. For the next four years, the Hungarian economy performed reasonably well, and Orbán remained extremely popular. In 2000, the European Union (EU) agreed to admit Hungary on January 1, 2004. Despite the improving economy and EU accession, Fidesz, to the surprise of many, lost the 2002 elections. Partly, the upset followed from Orbán's failure to clearly distance the party from extreme right-wing groups, which openly trafficked in antisemitic rhetoric and even celebrated the Nazi-allied regime that had ruled Hungary in the 1940s. The Socialist-Free Democrat coalition returned to power (Lendvai, 2019 \& Congdon, 2018).

During both the 2002 and 2006 campaigns, exorbitant social promises took center stage. The Medgyessy-cabinet (2002-2004) propagated its fiscal expansion under the slogan of a "welfare transition," hinting at the end of hardships and promising that Hungary's economic fortunes would quickly catch up to Western Europe after EU-accession (Deák, 2013). Orbán and his party spent the next four years in opposition and failed to win back power in the 2006 elections. Hungary had joined the EU with relative ease in 2004; within Europe, the country's social and economic standing was improving. However, among the populace, there was a growing distrust of the government (Timmer, Sery, Connable, \& Billinson, 2018).

\section{"Lie Speech," Im- age-Making, and Viktor's Victory}

\author{
A few months later after the elections, \\ a political bombshell exploded in Hun- \\ gary. An audio recording emerged in \\ September 2006, on which the Socialist \\ prime minister, Ferenc Gyurcsány, could \\ be heard delivering an internal, obsceni- \\ ty-laced tirade to fellow party members. \\ He described the country and his political \\ party in negative terms, hoping to con- \\ vince party members that some painful \\ economic reforms had been unavoidable
}


(Lendvai, 2019 \& Buzogány, 2017). In this rant, Gyurcsány even admitted to lying to the public.

This leaked speech became the spark that ignited the powder keg of social, economic, and political tensions that had been primed and ready to explode throughout Hungary. Protestors from all over the country flooded into Budapest. Wall-to-wall media coverage of what became known as Gyurcsány's "lie speech" fueled a massive and passionate attack by the opposition, with Orbán leading the charge against what he called an "illegitimate" government (Lendvai, 2019). Fidesz and the right-wing party Jobbik capitalized upon the protests and unrest, moving their platform further to the radical right. Fidesz especially rhetorically aligned

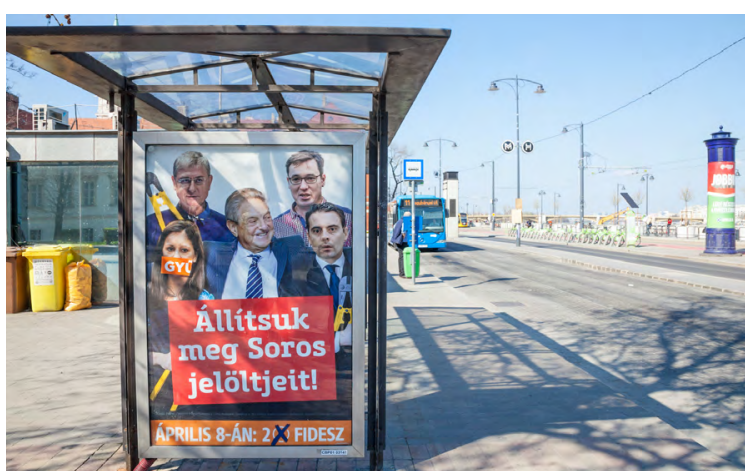

Poster from political party Fidesz showing the opponents of Hungarian PM Viktor Orban surrounding billionaire philanthropist George Soros, Budapest, April 8, 2017

themselves with the will of "the people" the protestors (Timmer, Sery, Connable, \& Billinson, 2018).

Despite public outcry and increasingly radical, violent protests on the streets of Budapest, Gyurcsány managed to stay in power for several years. However, the domestic political crisis was aggravated by the consequences of the 2008 global economic crisis and pressure from the EU to end deficit spending. Moreover, the population had had enough of technocratic reforms and permanent austerity without any context or end in sight. The 2008 crisis ushered in an era when an already disgruntled population was wary of reforms. Orbán became the last hope of a populace seeking change. Fidesz successfully combined social paternalism with the promise of large-scale tax reductions and a pro-market orientation. Thus, Orbán strengthened his claim on power, calling for an overhaul of the political system (Deák, 2013 \& Buzogány, 2017).

In 2008, Orbán also hired American-Republican strategist Arthur Finkelstein to re-create the flailing Fidesz's image. Finkelstein made a simple suggestion: exploit the ugliest legacies of Hungary's past. Orbán gleefully took up the charge, embracing the blood-and-soil rhetoric of Hungarian nationalism and laying into Jewish philanthropist George Soros as the symbol of all things globalized and sinister - even though he had worked for Soros's Open Society Foundations in the 1980s, back when he still had long hair, claimed he didn't believe in God and spoke out against nationalist bigotries (Sammon, 2019). They were well-positioned to easily sweep the parliamentary elections in 2010 (Timmer, Sery, Connable, \& Billinson, 2018).

Following the change in citizens' party preferences, the Hungarian party system, formerly composed of two poles of nearly equal strength, collapsed. In the 2010 elections, Fidesz and its partner won 57 percent of the popular vote and gained an unprecedented two-thirds majority in Parliament (263 seats) (Illés, Körösényi \& Metz, 2018). This was a first in the history of democratic Hungary. In the nearly decade since, Orbán has used this supermajority to transform Hungary's constitution, institutions, economy, foreign policy, and society. After what he deemed a "revolution at the ballot box," Orbán proudly announced the drafting of an entirely new constitution, called the Fundamental Law of Hungary, despite never mentioning constitutional reform during the electoral campaign (Lendvai, 2019) and despite opinion polls showing that less than one-third of the Hungarian population saw the need for a new constitution (Illés, Körösényi \& Metz, 2018).

According to a joint article by lllés, Körösényi, and Metz, Orbán's aims with constitution-making were multiple. First, the new constitution became a symbolic expression of revolutionary change and the founding moment of a new regime. In addition to representing a dramatic break with the post-communist regime, the new constitution also incorporated such 
potent symbols as the Hungarian "Holy Crown." Second, it represented a break with the "legal constitutionalist" (Bellamy, 2007) approach which had characterized the previous regime and supported the supremacy of judicial review over politics. Third, constitution-making became Orbán's means of weakening and de-legitimizing authorities which were interwoven with the status quo, such as the constitutional court, the "ombudsman," media authorities, and the central bank (Illés, Körösényi \& Metz, 2018).

In 2011, the new constitution was rushed through parliament in nine days without any input from the public, much less a referendum. The main victim of the new constitution was the judiciary, especially the Constitutional Court. Previously, the powers of the executive branch were limited by a high number of constitutional laws and their extensive interpretation; this meant giving the opposition a check on the majority's power (Deák, 2013). Now, the justices of the Constitutional Court would be selected not as they had been before, through an all-party parliamentary committee, but directly by Parliament. With Fidesz holding a supermajority in parliament, Orbán could pack the court with sympathetic judges.

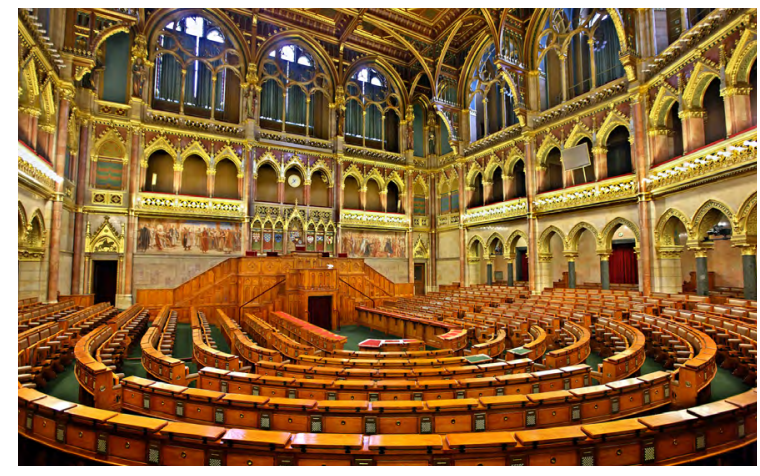

The chamber of the Lower House of the Hungarian Parliament in Budapest.

\section{Legislative Tsunami \& Invasion of Party Apparatchiks}

According to some observers, Orbán's constitution-building efforts were designed to re-affirm some of the com- mon values and constitutional traditions shared by the community in the past or which he sought to create anew through the new constitution. First, the constitutional discourse of Orbán's party recalled the Christian and national traditions that were prevalent in Hungary prior to the communist era. Second, the Hungarian nation is defined in an ethnocentric way in the Fundamental Law, which not only symbolically embraces the ethnic Hungarians of neighboring countries in the constitution, but enfranchises them to participate in Hungarian general elections through a newly introduced dual-citizenship scheme (Illés, Körösényi \& Metz, 2018).

Furthermore, Parliament also legislated 365 new laws (an average of one every 1.5 working days) through early 2012, among others the new constitution and all 25 constitutional laws. This was an unprecedented legislative tsunami, not comparable even to the transition from communism (Deák, 2013). Orbán also chipped away at the top court's authority: among other assaults, in 2013, the Fidesz-dominated Parliament voted to strip the Con-

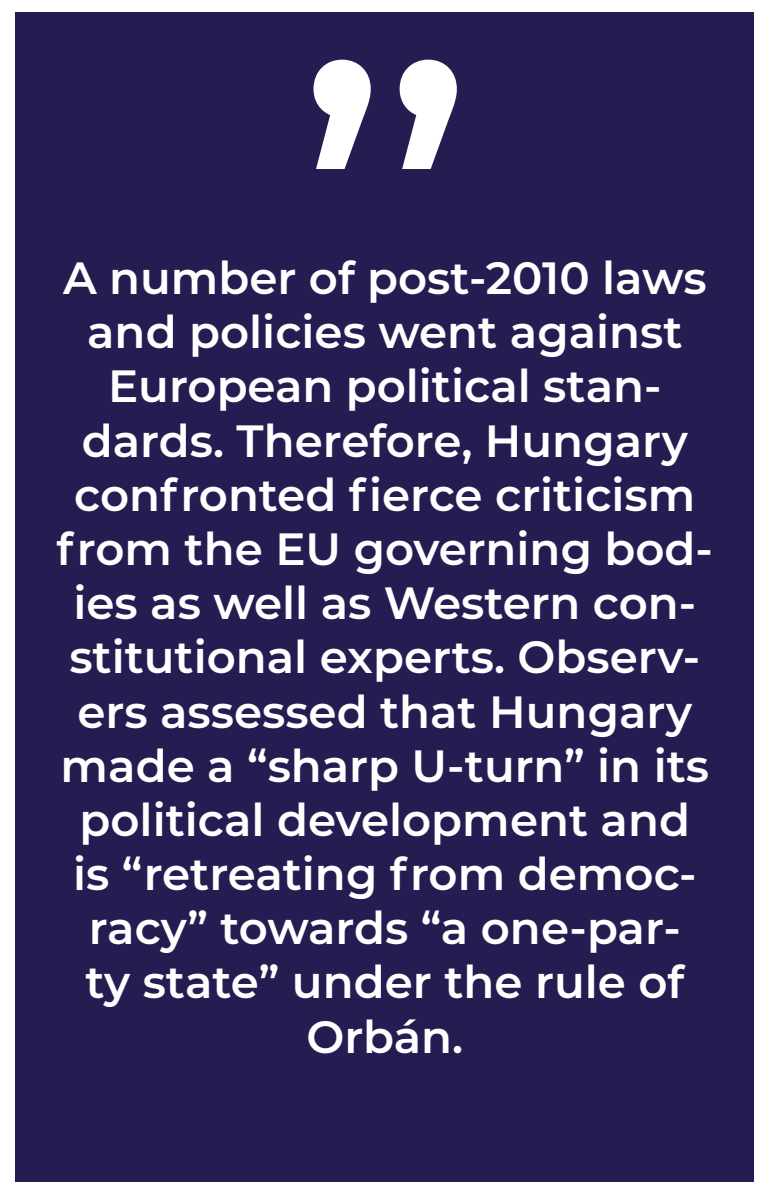


stitutional Court of the ability to review laws concerning state finances and wrote directly into the constitution a number of Fidesz-backed laws that the court had previously overturned (Lendvai, 2019). Orbán also handed personal friends and loyal party apparatchiks long-term posts in the corridors of power, including the President of the State, the State Audit Office, and the Constitutional Court, as well as top positions in cultural institutions such as the state media, the film industry, and state universities (Fabry, A., \& Sandbeck, S. 2019).

The process lasted from 2010 to 2015 and became an essential part of the political struggle between Orbán's legislative majority and the constitutional forces representing the status quo, including the Parliamentary opposition, the Constitutional Court, non-governmental organizations (NGOs) and prominent constitutional lawyers. Clashes with international actors such as the EU Commission, the European Parliament, the Venice Commission, and the US government, who all expressed concern about certain changes in the constitution, were perceived and framed in Orbán's political discourse as part of his cabinet's "freedom fight" - an effort to regain Hungarian national sovereignty (Illés, Körösényi \& Metz, 2018).

A number of post-2010 laws and policies went against European political standards (Batory, 2015). Hungary confronted fierce criticism from the EU governing bodies as well as Western constitutional experts. According to some vocal opponents of the post-2010 developments, the Orbán government "have downgraded or done away with the checks and balances that are widely considered essential for the rule of law" (Rupnik, 2012) and departed from the norms of democratic pluralism (Kovacs and Toth, 2011 \& Bayer, 2013). Other observers are even more pessimistic, arguing that Hungary made a "sharp U-turn" in its political development and is "retreating from democracy" (Kornai, 2015) towards "a one-party state" (Scheppele, 2014) under the rule of Orbán (Shevchenko, 2018).

The European Parliament's Hungary Rapporteur Judith Sargentini (Sargentini, 2018), a Dutch MEP, also noted in a detailed report, released on Sept. 11, 2018, nu- merous problematic institutional changes in Hungary. According to the report, the freedom and independence of the judicial system are threatened. The first constitution written on an iPad has curtailed the role of the Constitutional Court. Meanwhile, a new and less independent court system is being introduced which will deal with legal cases brought against the government. The government has also limited the people's right to strike and to protest, and media freedom is under pressure as the government advertises exclusively in loyal media outlets (Zsuzsanna, 2019).

Sargentini also documents Orbán's other transgressions, from widespread corruption to the forced sterilization of Roma women. She took to the floor of the European Parliament and called on her colleagues to choose: "Will you ensure the value of this union is more than just words written on a piece of paper?" Supporters of the Hungarian populist, including Nigel Farage, the chief cheerleader for Brexit, came to Orbán's aid (The Economist, 2018). However, in September 2018, the European Parliament responded to the report that condemned the regime's anti-democratic policies by voting 448197 (with 48 abstentions) to invoke seldom-used Article 7, also called the "nuclear option," against Hungary, launching proceedings that could lead to sanctions against the country, including suspension of its voting rights in the European Council (Encyclopædia Britannica, 2020).

In doing so they collectively stated that Orbán's government posed a "systemic threat" to democracy and the rule of law. However, Orbán did not care all that much about the vote. His primary audience in Strasbourg was not MEPs but domestic voters, and the defeat will only serve to boost his popularity, as he presents himself as a valiant defender of the beleaguered Hungarian nation against hostile external forces. "These debates help him to mobilize his own camp and will work much more at a domestic level," said Andras Biro-Nagy of Policy Solutions, a Budapest think-tank. Fidesz's lead in the polls is unassailable. More than 50 percent of Hungarians back it against a fractured opposition (The Economist, 2018). 

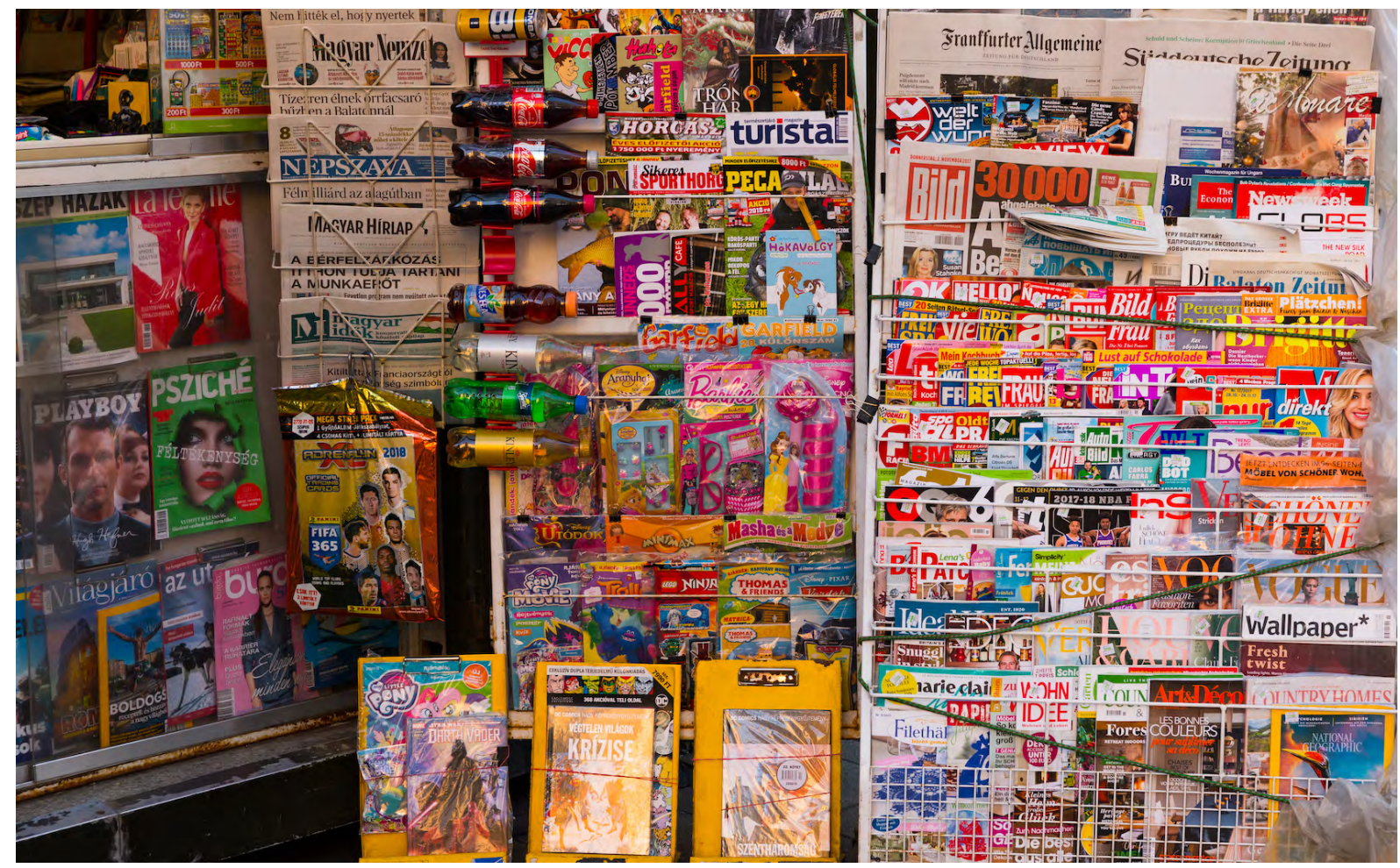

Newsstand with newspapers in Hungarian in the center of Gyor, Hungary on November 3, 2017.

\section{Hungarian Media Monopolized and Silenced}

The media have always been in Orbán's sights. He blamed his party's defeat in 2002 on the publicly funded media networks and had long dreamed of hobbling them. With his majority support in Parliament, he brought together all the government-funded television and radio networks under a new conglomerate run by Fidesz supporters. Later, he also established a centralized media authority - the National Media and Info-communications Authority - with the responsibility to regulate the media industry and media content. Its five-member council is elected with a two-thirds supermajority by the Fidesz-dominated Parliament. The organization, which has received widespread criticism for jeopardizing the freedom of the press, has the right to deny media outlets their licenses and impose heavy fines of up to 200 million forints $(\$ 860,000)$ on journalists and media outlets for publishing articles with "improper content." As a result, the public networks are more tightly supervised by Fidesz today than they were in the final period of the communist regime. Such control is made possible because the majority of Hungarians get their news from television (Lendvai, 2019; Fabry \& Sandbeck, 2019 \& Timmer, Sery, Connable, Billinson, 2018). Thus, Hungary's position on the World Press Freedom Index, compiled by Reporters Without Borders (RSF), has plummeted from 23rd in 2010, when Orbán took power, to 89th in 2020 (RSF, 2020).

Further erosion of press freedom occurred in 2018 when all pro-Fidesz media owners "donated" their holdings to a new structure run by three of Orbán's most trusted lieutenants. Dubbed the Central European Press and Media Foundation, the organization now consists of 476 media outlets. The government has exempted it from legal scrutiny and from regulations governing the concentration of media holdings (Lendvai, 2019). Today, Orbán has a far greater ability to control the Hungarian mediascape, and justifies his control of media outlets, claiming that unchecked they become "enemies of the state" (Timmer, Sery, Connable \& Billinson, 2018). Except for one television station owned by a German company (RTL), a small radio station heard only in Buda- 
pest, and a few culture-focused weeklies, every single media outlet in the country is now controlled by people close to the regime. So, the government's introduction of the latest tax on advertising revenue appeared to have been specifically targeted at handcuffing the commercial broadcaster RTL (Encyclopædia Britannica, 2020).

Media researcher Péter Bajomi-Lazar has explained that in a plural landscape, media doesn't have much of an impact, but in Hungary, media have been put in the service of a majoritarian government dedicated to establishing ideological hegemony in an attempt to change longterm public opinion and voting behavior, thus cementing its power (Howden 2016). According to Hungarian media observers, the government control of the media is successful because the mediascape is small, limited in scope, and relatively homogenous. Furthermore, Orbán is able to manipulate media messages to create the illusion of openness. There are only three broadcasting services in Hungary. The national station, MTVA, is essentially the mouthpiece of the government. Of the other two commercial stations, TV2 is now basically turning into another governmental channel. As mentioned previously, RTL is still standing but is under constant pressure (Timmer, Sery, Connable \& Billinson, 2018).

Control of the media, however, is not limited to control of broadcast television. Print and online journalists also have found themselves under attack. In an article for the Web site Refugees Deeply, Daniel Howden provided examples of journalists from origo.hu (a well-known left-leaning online news source) and the Budapest Business Journal, who felt pressured to alter their stories or resign (Howden 2016). In both cases, the journalists resigned rather than compromise their ethics. In 2011, Klubrádió, news and talk radio station, known to be the voice of left/ liberal opposition, was denied renewal of their license; they'd begun broadcasting in 1999. This led to a fairly long legal battle which Klubrádió eventually won in 2013 (Timmer, Sery, Connable \& Billinson, 2018). As Tamás Bodoky of Átlátszó (Transparent), a civil watchdog organization asserted, "there are fewer and fewer workplaces for journalists willing to expose corruption and they mostly exist on the internet" (Bienvenu 2016).

Perhaps the most notable example of the government's overreach is the sudden closure of the country's long-standing newspaper, Népszabadság. On September 30, 2015, the paper, one of the premier leftist national newspapers, was suddenly shut down. The owner cited loss of readership and loss of revenue, but employees saw the closing as Orbán's doing. Journalists showed up to work only to find they were out of a job. Online readers logged on that morning to find a letter explaining the closure. Even the archives were removed. The closure of Népszabadság is seen as highly symbolic. The word 'népszabadság' means the people's liberty. The paper was founded during the 1956 Revolution and is associated with the spirit of the people's rebellion (Timmer, Sery, Connable \& Billinson, 2018). 


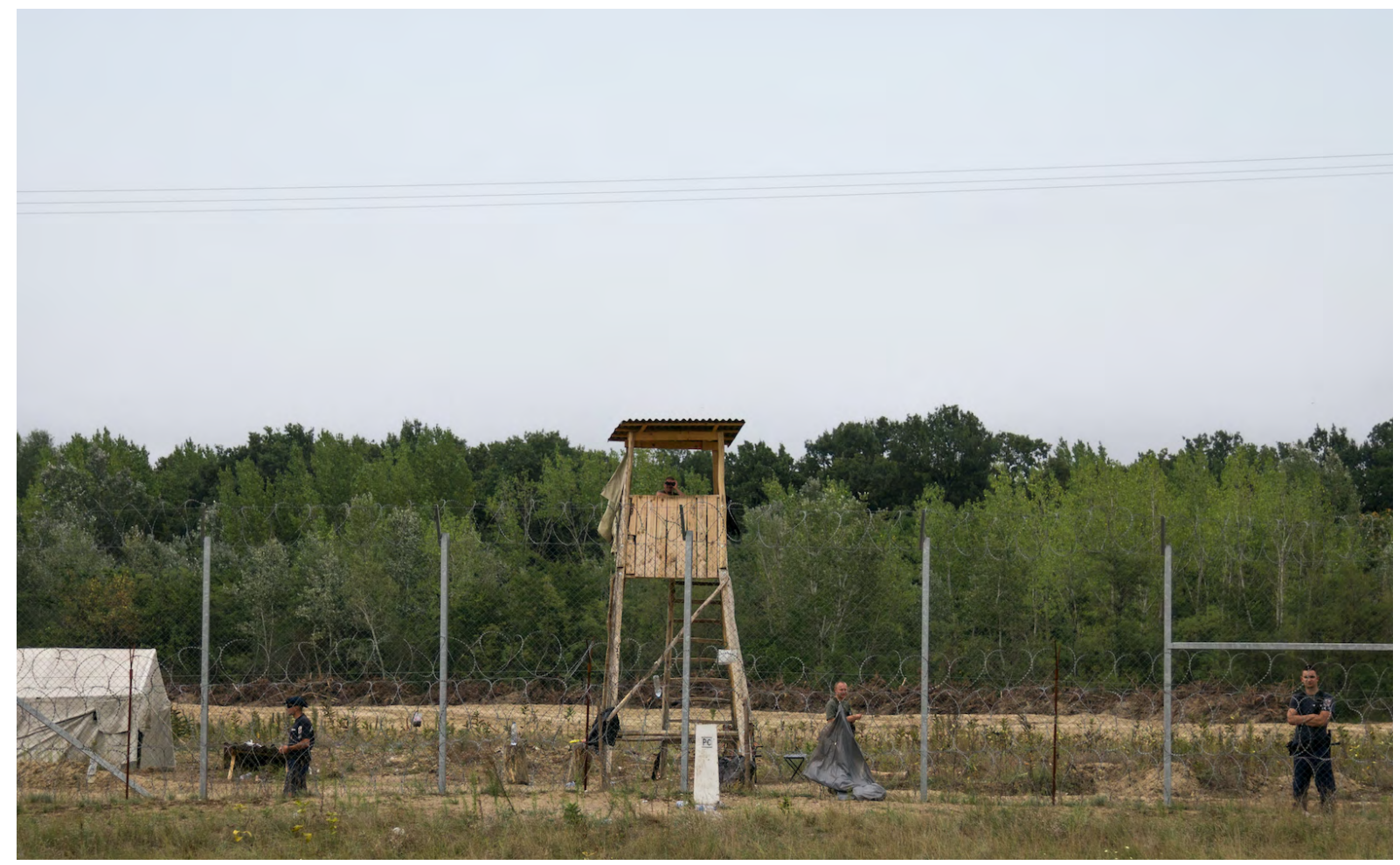

Hungarian policemen watching the Serbian Hungarian border fence in Kelebija, Serbia on September 10, 2016. This wall was built in 2015 to stop the refugees passing through Serbia and the Balkans Route.

\section{Immigrants: An Op- portunity to Create a New Enemy}

In 2015, when the European migrant crisis erupted, Orbán saw an opportunity to create a new enemy. Illegal immigrants hoping to transit to western Europe flooded from the Balkans to Hungary. More than 200,000 refugees and economic migrants besieged the external border of the EU (Rydliński, 2018). At one point, about a thousand migrants were trying to board trains for Germany. The sight of the chaos frightened Hungarians, and Orbán's government has done everything in its power to keep this fear alive (Zsuzsanna, 2019). Dysfunctional European crisis management and a series of terrorist attacks and other related incidents provided space for Orbán to create a narrative of fear around immigration (Huysmans, 2000 \& Szalai A., Göbl G. 2015). In response, his government offered the Hungarian people security.

Through populist rhetoric, Orbán raised the stakes of the crisis, making a clear connection between illegal immigration, organized crime, and terrorism. Initially, his crisis narrative (Metz, 2017) focused on the impact of immigration on the economy, culture, and public safety; then, over time, he focused more on the lack of confidence, leadership, and democracy in the EU, and the collapse of a European Christian identity. In addition, he strongly opposed the European liberal and leftwing political elite, namely "Brusselian bureaucrats" and civil activists. To support this narrative, Orbán, with support from Slovakia, initiated legal action against the EU's plan for migrant re-settlement at the European Court of Justice in December 2015. His government claimed that the decision infringed upon established EU law (Illés, Körösényi \& Metz, 2018). However, Prime Minister Orbán was not satisfied with his diplomatic, political, and legal efforts. He ordered the erection of a metal fence on Hungary's southern border.

At present, the average number of migrants or refugees trying to enter the country in a week is only 10, but the propaganda against migration continues. There is a designated border patrol police unit, taking its name "határvadászok" or "border hunters" from a WWII military 
unit deployed to chase Serbian insurgents. This was meant to appeal to the followers of Jobbik, which long promised to bring back the Border Guards dismissed 25 years ago, with the fall of the Communist regime (Haraszti, 2015). The government also declared a state of emergency in 2015, which has been extended to the present. The public media, influenced by Fidesz, still broadcasts unfavorable news about immigrants and refugees. (Zsuzsanna, 2019).

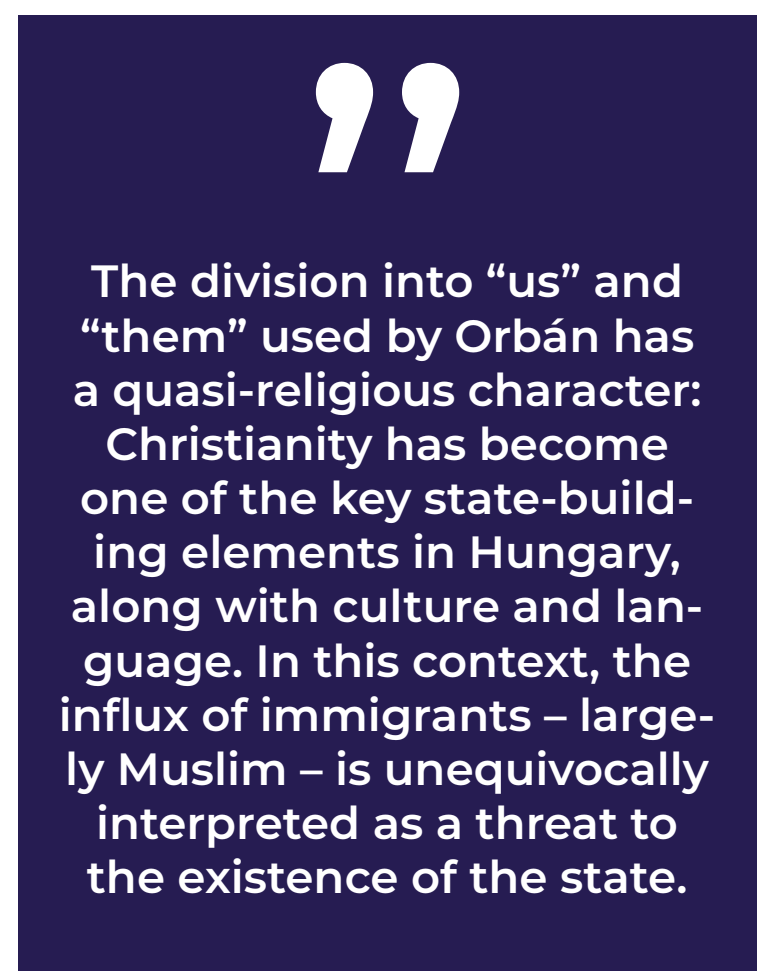

German Chancellor Angela Merkel's "policy of open doors" has been met with heavy criticism within Central European countries, with Orbán as the undisputed leader of the backlash. Initially, Orbán used two main arguments. First, a legal one, concerning the Dublin Convention stating that the asylum motion should be decided on in the first EU country the refugee reaches. The second argument was political, and it concerned the threats to Hungary's identity and security from Muslim migrants. From the legal perspective, Orbán's point of view fits into the norms of abiding by international law. However, the use of language generating fear of Islam - or the use of outright Islamophobia - has a strictly illiberal character. As Dominik Héjj pointed out, the division into "us" and "them" used by Orbán also has a quasi-religious character: "Christianity has become one of the key state-building elements in Hungary, along with culture and language. In this context, the influx of immigrants - largely Muslim - is unequivocally interpreted as a threat to the existence of the state" (Illés, Körösényi \& Metz, 2018).

Orbán utilized the well-known symbol of Central Europe as the "Bulwark of Christianity," an important element of Central Europe's regional identity. He wanted to prove that in the refugee crisis, Hungary was once again taking part in a historical "clash of civilizations," and that as a special nation, it had to withstand not only attacks from outside of Europe but also from within (Illés, Körösényi \& Metz, 2018). However, Orbán has had to walk a fine line. While he loudly campaigns against immigration, Hungary is in desperate need of additional labor. Hungarian companies offer work visas to Ukrainians and various Latin American nationals. Thus, the anti-immigration campaign in Hungary has become narrow in scope, and it has strong Islamophobic and racist undertones (Zsuzsanna, 2019).

This cynical attitude was not a secret. Orbán has time and again presented himself and his government as "the last defenders of a Europe based on the nation, family, and Christianity" (Lendvai, 2019). Orbán interpreted the migration crisis as an enormous threat, not just against the welfare state and public security, but also against Christian civilization, European values, and nation-states. One of the messages posted on a government billboard during a period of campaigning made this standpoint explicit: If you come to Hungary, respect our culture! Orbán provided a strong vision of a Christian Europe, contrasting this vision with Islamic culture and consciously promoting his own role as defender of the Schengen-area borders and of "old Europe" and "real" European values. According to Orbán's vision, there is no need for the further integration of immigration policy, because only nation-states can manage the crisis effectively. He not only challenged the EU's role in the country but also created broad public support for his policies. Orbán used the migration crisis to redefine and revitalize the role of nation-states (Illés, Körösényi \& Metz, 2018). 
It's easy to understand Orbán's intended audience by studying the billboards: they were written in Hungarian, a language that most asylum seekers from the Middle East and Northern Africa do not speak. Like the fence, these billboards sent a message to Hungarians: that they were under threat but that their government could protect them (Timmer, Sery, Connable \& Billinson, 2018). Accordingly, the Hungarian Parliament tightened the legal framework for asylum seekers and illegal immigrants. On June 7, 2016, the governing alliance of Fidesz-KDNP and the right-wing opposition Jobbik approved the Sixth Amendment to the Fundamental Law, which widened the government's emergency powers in the case of significant and direct risk of a terrorist attack (Illés, Körösényi \& Metz, 2018).

Orbán's government has made a life for migrants in Hungary extremely difficult. But this was not sufficient for Orbán. In 2017, Parliament passed another law forcing all asylum seekers into detention camps, with some of them housed in converted shipping containers. Amnesty International condemned the measures as "illegal and deeply inhuman" and "a flagrant violation of international law" (Amnesty International, 2017). A report issued by the Council of Europe (COE) in 2019 charged that refugees in Hungary were being deprived of food and denied legal representation. The CoE's Human Rights Commissioner, Dunja Mijatovic, said that the Orbán government's anti-immigration stance was "fueling xenophobic attitudes, fear, and hatred among the population." She reiterated that many asylum seekers held in transit zones had been deprived of food (BBC, 2019).

Orbán's anti-immigrant campaign took another turn when the EU tried to introduce a Common European Asylum System under which Hungary would have had to evaluate the asylum claims of a limited number of migrants who entered the EU from another country (Zsuzsanna, 2019). Orbán did not hesitate to cast the migrant influx as the product of a conspiracy among hostile foreigners and corrupt elites: "The most bizarre coalition in world history has arisen," he declared, "one concluded among human smugglers, human rights activists, and Europe's top

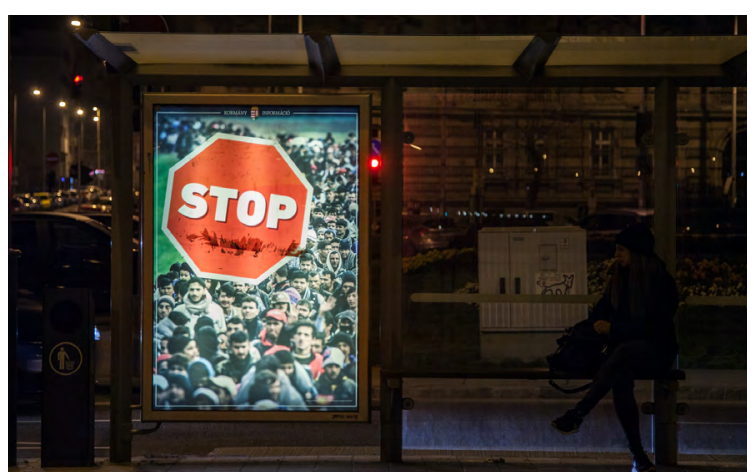

Anti Immigration poster from Viktor Orban government in the streets of Budapest during the 2018 general elections campaign.

politicians in order to deliver here many millions of migrants. Brussels must be stopped!" (Lendvai, 2019). Orbán started a countrywide "Stop Brussels" campaign, in which the government insinuated that the EU wanted to settle migrants in Hungary. However, this campaign was still somewhat vague. To personalize the enemy, he added his former sponsor George Soros as the mastermind behind the asylum plan. The billboards changed from the message "Stop Brussels" to "Stop Soros" with a picture of the Hungarian-born American billionaire (Zsuzsanna, 2019). Orbán also passed a "Stop Soros" law making it illegal to help migrants (Beauchamp, 2018).

In the domestic arena, Orbán put great emphasis on dominating public discourse and applied a plebiscitary strategy to support his messages. In April 2015, the government launched a so-called "national consultation" regarding the migrant crisis. This suggestive political questionnaire, mailed out to citizens, involved issues such as terrorism, the economic impacts of immigration, and the incompetent politics of the $\mathrm{EU}$ and resulted in the government raising the terror-threat level (Spike, 2017). To legitimize its anti-immigration policy, the government also initiated a referendum about the EU's compulsory migrant resettlement quotas, which was held on October 2, 2016. The low turnout resulted in the invalidation of the referendum, although the overwhelming majority of voters rejected the EU proposal for a migrant quota (BBC, 2016). The turnout was only 44.04 percent, which did not reach the threshold for validity, 50 percent. In all, 98.36 percent of the participants rejected the EU's 
quota proposal (National Election Office, 2016). Since Orbán's migration narrative lacked a "brüte" ground - very few refugees desired to remain in Hungary - the "migration threat" emphasized by the government appeared imaginary to major segments of the population. This absence of migrants was probably one of the main factors which contributed to low voter turnout for the referendum (Haraszti, 2015; Illés, Körösényi \& Metz, 2018).

Orbán did not stop his campaign. He continued to rage against both the "mostly Muslim" refugees and "Europe" that was "mentoring them." He cast the refugees as profiteering pseudo-victims, many of them actual lawbreakers and some potential terrorists; at best, they were tools invited to Hungary by multinational capital and left-wingers in an effort to ruin Hungary through liberalism and multiculturalism. To Orbán's supporters, the narrative was straightforward: "The EU and liberals hate us because we Hungarians are building an illiberal state and have never adopted multiculturalism, which has already ruined the West. And while we show the world how to remain migrant-free, culturally separate, and homogenous, we nevertheless also do this while defending European Christianity." Orbán has weaponized latent xenophobia, one that had its roots in Hungary's territorial losses after the 1918 collapse of the Habsburg commonwealth. To this day, he continues to generate new domestic and international conflicts, posturing as the defender of national interest (Haraszti, 2015).

Orbán's focus on nationalism and his anti-immigrant rhetoric only escalated in the run-up to general elections in April 2018. He cast himself as the protector not only of Hungary but also of Christian Europe against a supposed invasion of "nefarious Islamic immigrants," despite the reality that the wall on the country's southern border virtually eliminated ingress into Hungary, for both migrants and refugees. Orbán has continued to claim that the opposition, Soros, the EU, and the United Nations (UN) are conspiring to transform Hungary into a country of immigrants. Fidesz and Orbán have used their dominance of the media to drive home this message with xenophobic fearmongering.
As one political analyst claimed, "as long as migration is top of the agenda, Orbán's and Fidesz's popularity goes up. They have to keep up the momentum" (Howden 2016). 


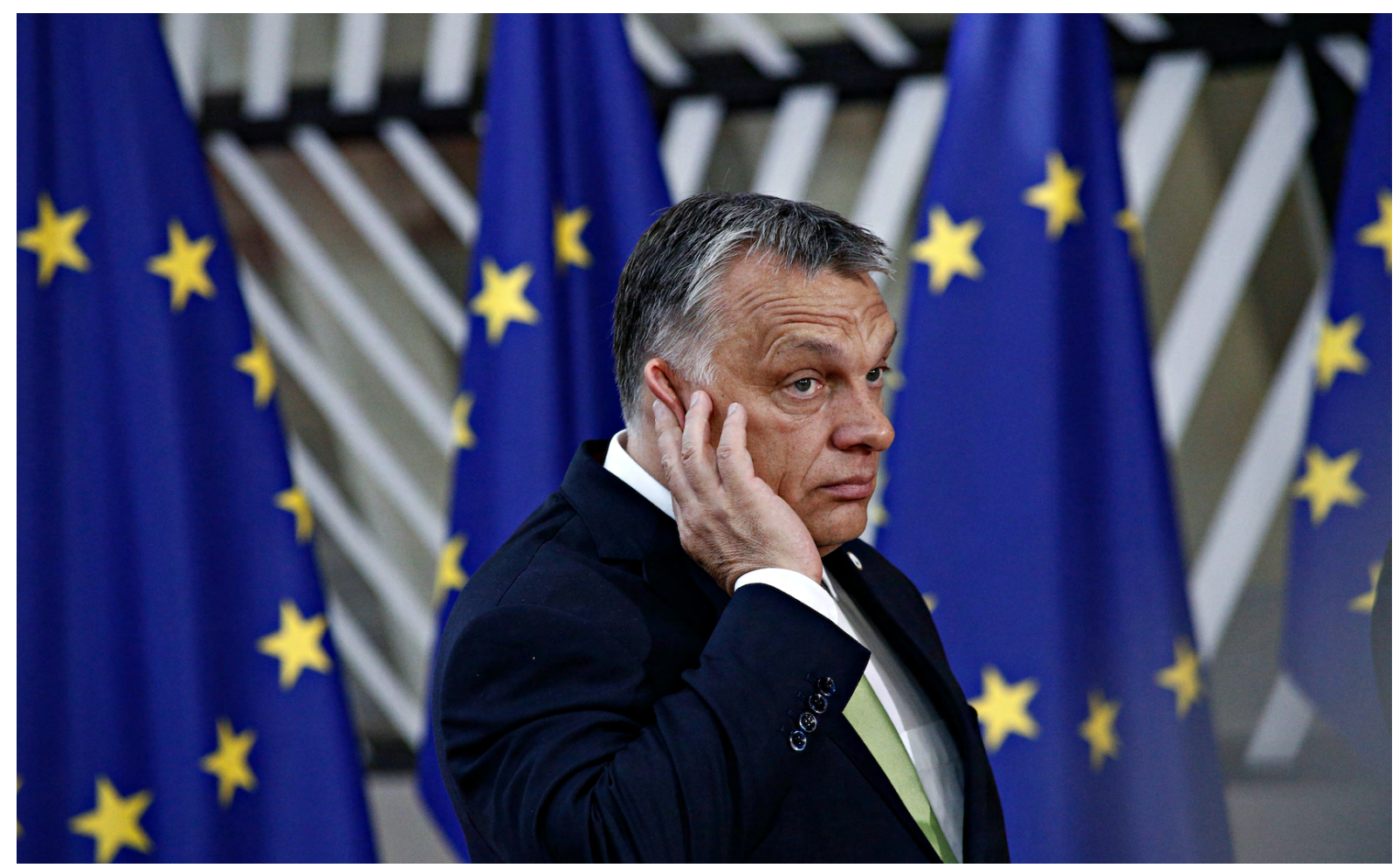

Viktor Orban was in Brussels for a meeting with European Union leaders on June 22, 2017.

\section{A Prototype of a Populist Eurosceptic}

Since coming to power in 2010, Orbán has consistently disdained judicial independence, academic and media freedoms, and the rights of migrants. He has, in the view of many people, run roughshod over some of the EU's core values. So far, however, the EU has done nothing solid to rein him or his government in (The Economist, 2018). Orbán's authoritarian tendencies and hostility to liberalism are ironic, considering he came to power as part of Hungary's dissident, anti-authoritarian movement. Even more ironic is his closeness to Russia and Vladimir Putin. Putin's autocratic ethnic nationalism has become a model for the politics of Orbán and the Hungarian Right. Thus, a "greater Hungary" rhetoric that champions the rights of Hungarians outside the country's borders and whips them into a fury has become an inseparable part of Orbán's populist nationalism. This ethnic nationalism, which recalls the days of the Austro-Hungarian Empire, is essential for creating a political consensus to underpin Orbán's authoritarian ambitions (New Internationalist, 2014).
While ethnonationalism has rallied support at home, the migrant crisis has eroded support for the EU. Since Orbán came to power, Hungarian trust in the EU has decreased significantly; and by 2016, levels of xenophobia in Hungary had reached a record high (Illés, Körösényi \& Metz, 2018). Although Orbán's populist ethnic nationalism has taken a huge toll on people's trust in the EU, things started to change even before he came to power: the share of respondents who think that the EU-accession proved useful fell from 71 percent to below 40 percent between 2001 and 2009. Those who perceive the EU as a negative entity rose from 7 percent to 22 percent during the same period. Today, skepticism has turned into open hostility, and national and European interests tend to be more and more differentiated (Deák, 2013).

\section{Was this split inevitable?}




\section{1}

Although the EU has criticized the Orbán regime for dismantling liberal democratic institutions and state-sponsored corruption, it continues to provide much-needed financial assistance to Budapest in the form of EU Cohesion funds.

The situation cannot be understood without analyzing the historical context. The dissolution of the Hungarian Kingdom after WWI and the loss of two-thirds of the country's territory are often cited as reasons for why Hungarians are skeptical of the West. Indeed, the Trianon Peace Treaty of June 4, 1920, is still perceived as unjustified and unfair by the overwhelming majority of the population (Deák, 2013). The mainstream historical narrative, believed especially by conservatives, is that much of the guilt lies with the Western powers' realpolitik. For Hungary, the years after WWI were full of despair and anti-Western sentiments. Few Hungarians, liberal or conservative, have positive memories of the role of the Western powers, especially as far as the twentieth century is concerned. Thus, measures applied by the Orbán government, such as closing the southern borders and tightening immigration laws, had broad cross-party support. Meanwhile, constant criticism of his regime-building strengthened Orbán's Eurosceptic position.

Although the EU has criticized the Orbán regime for dismantling liberal democratic institutions and state-sponsored corruption, it continues to provide much-needed financial assistance to Budapest in the form of EU Cohesion funds. Brussels has also looked on haplessly at the Orbán regime's has orchestrated closer ties with authoritarian regimes, such as Erdogan's Turkey or Putin's Russia, and pursued increasingly explicit overtures to the far-right in Hungary and abroad, including the Austrian Freedom Party (FPÖ) and the Polish Law and Justice Party (PiS) (Buckley and Foy, 2016). There has been relentless speculation in the media about German Chancellor Angela Merkel losing patience with Orbán's authoritarian policies and his open criticism of the German government's "open-door" refugee policy (Werkhäuser, 2015), but up to present she has continued to support his party in the European Parliament where Fidesz sits together with the CDU-CSU in the European People's Party, EPP (Fabry \& Sandbeck, 2019).

On this fertile ground for nationalist populism, Orbán went a step further by calling for an illiberal society based on radical cuts in social services. He has also taken to celebrating "the wind from the east" blowing from "success stories" like Putin's Russia and Erdogan's Turkey, as well as China. This has been accompanied by the usual moral rhetoric of the populist Right: homophobia, restrictions on abortions, calls for social discipline, and scapegoating of ethnic and religious minorities. Meanwhile, the neo-fascist party Jobbik has organized paramilitary thugs who increasingly push Fidesz to the right, exacerbating the threat to Hungary's Roma and Jews (New Internationalist, 2014).

Despite Orbán's massive illiberal moves, Hungary is by default still a democracy due to its membership in the EU. In order to be considered for admission, prospective countries must demonstrate an adherence to EU values such as freedom of speech, religion, press, and movement. However, Prime Minister Orbán is miles away from these ideals, has unabashedly decried liberal democracy, and instead favors an illiberal nation. In a 2014 speech given in Băile Tuşnad, Romania, he proclaimed, "The Hungarian nation is not a simple sum of individuals, but a community that needs to be organized, strengthened and developed, and in this sense, the new state that we are building is an illiberal state, a non-liberal state" (Orbán, 2014). 
A "Russian Trojan Horse" inside the EU and NATO?t

In this speech, Orbán openly attacked liberal democracy, and he mentioned Singapore, China, India, Turkey, and, above all, Russia as examples to be followed. Subsequently, he has spoken of illiberal or Christian democracy. "Liberal democracy," he has observed, "is no longer able to protect people's dignity, provide freedom, guarantee physical security, or maintain Christian culture" (Congdon, 2018). Orbán recognizes that his policies are unaligned with democratic ideals but makes the argument he is acting in accord with the Hungarian community. In the same speech, Orbán explained, "systems that are not Western, not liberal, not liberal democracies and perhaps not even democracies, can nevertheless make their nations successful" (Timmer, Sery, Connable \& Billinson, 2018). He continued, "Societies that are built on principles of liberal democracy will probably be incapable of maintaining their global competitiveness in the upcoming decades and will instead probably be scaled down unless they are capable of changing themselves significantly" (Orbán, 2014).

Orbán's July 2014 speech garnered substantial attention both domestically and internationally. The Western political establishment was further shocked by his embracing the idea of an "illiberal state." Fareed Zakaria, the author of a much-cited piece coining the term "illiberal democracy," opined that Orbán was establishing a Hungarian-version of "Putinism" (Zakaria, 2014). Others saw the Hungarian government as a "Russian Trojan Horse" inside the EU and NATO. Academics wondered:" How can you sleep under your NATO Article 5 blanket at night while pushing 'illiberal democracy' by day; whipping up nationalism; restricting free press; or demonizing civil society?" charged Victoria Nuland, a US Assistant Secretary of State for European and Eurasian Affairs, in her keynote address to the October 2014 US-Central Europe Strategy Forum (Rettman, 2015).
Despite the massive reactions he drew, Orbán reiterated his illiberal views during his State of the Nation address in February 2015 and spoke about the decline of the liberal Western model of political and economic development underscored by the 2008 financial crisis. He called for "breaking away from dogmas and ideologies recognized in Western Europe" and basing the Hungarian statehood on "national foundations." Orbán argued that the goal of creating an efficient state capable of making a nation successful and globally competitive requires adopting political and economic institutions that might not conform to Western liberal democratic standards, and once again he cited the examples of Singapore, China, India, Turkey and Russia (Rydliński, B. 2018).

These words were not just political rhetoric. In an attempt to reduce Hungary's excessive dependence on the EU and the US, he has steadily reoriented Hungary's foreign policy, pulling the country away from the liberal democracies of western Europe and making common cause with other strongmen and populist parties. Indeed, there is barely a dictator in the world for whom Orbán does not have praise (Lendvai, 2019). He started to promote an "Eastern Opening," a policy aimed at amplifying economic ties with Russia and the Asia-Pacific. Orbán, one of Russia's harshest critics in Central Europe in the past, expanded bilateral ties and encouraged Russia to invest in the Hungarian economy. In 2014, just as the EU and the US were preparing to sanction Russia for its annexation of Crimea, and at a time when Brussels was urging $E U$ member states to reduce their dependence on Russian energy (Lendvai, 2019), the Orbán government signed a number of long-term partnership agreements with Russia's Gazprom. Hungary also opted for several large-scale investments involving major Russian companies; these include the public tender to modernize the Budapest metro, which was won by the Russian Metrovagonmash (Buzogány, 2017).

Orbán went on pursuing profitable deals with Moscow while avoiding strategic commitments and preserving both security ties with NATO and the economic benefits of the EU membership. Hungary 
also signed a long-term agreement with Russia's Rosatom to expand Hungary's single Soviet-era nuclear Paks plant, with the construction financed by $\$ 13.33$ bn., a 30-year loan from Moscow (Rydliński, B. 2018). The contract was announced without any feasibility study or public tender, and the exact details remain hidden from the public. In sum, this suggests "that the Hungarian government's desire to create domestic economic benefits takes precedence over its Euro-Atlantic orientation" (Buzogány, 2017).

Orbán has taken a step further and institutionalized his new orientation by establishing the "Ministry of Foreign Affairs and Trade" which was led by one of his young followers, Péter Szijjártó. He declared attracting investments and foreign trade to be the main priority of Hungarian diplomacy. Szijjártó was also assigned responsibility for the new "Eastern opening." At the same time, the restructuring of the ministry, which was marked by establishing a department dealing exclusively with Chinese and Russian affairs, was paralleled by excessive purges in the diplomatic corps. Around 400 seasoned diplomats with strong Euro-Atlantic credentials were dismissed from the ministry and replaced by young professionals from Szijjártó's entourage, most of them lacking a background in foreign policy.

Fidesz's own foreign policy experts, most of them Atlanticists, lost influence, too. The Eastern opening has also brought back to the forefront sidelined pro-Russian diplomats, many of them Soviet-trained alumni of the elite diplomatic academy Moscow State Institute of International Relations (MGIMO). Among the newcomers designing the policy were some Russia "experts" with dubious credentials and alleged ties to the Russian criminal underworld. In any case, the influx of new personnel without a deep understanding of diplomatic practices made Hungarian diplomacy largely unable to assess the situation into which the country had maneuvered itself within the EU (Buzogány, 2017).

Hungary's "Eastern turn" also becomes apparent when looking at statistics of Orbán's foreign visits; Mideastern and far Eastern destinations gradually replaced meetings with Western or Central and Eastern European leaders. In July 2018, Orbán traveled to Turkey to attend the inauguration ceremony of re-elected Turkish President Recep Tayyip Erdogan (About Hungary, 2018). In April 2019, Orbán attended China's "Belt and Road" forum in Beijing, where he met the Chinese President Xi Jinping (China Daily, 2019). Traveling to Central Asia in 2014 and 2015 , Orbán was repeatedly cited praising political stability and the economic development in countries such as Kazakhstan, highlighting the common ethnic kin and genealogical differences between Hungarians and Western Europeans and making vague references to the "Turanian tradition" of interbellum fascist Hungarian political thought, which emphasizes Turkic and Asian elements in Hungary's cultural heritage and is promoted excessively by the Hungarian radical right-wing (Buzogány, 2017).

Orbán's opposition to immigration has further distanced him from Western Europe. He claims that his anti-immigrant stance is the only right and moral one. For example, in a March 15, 2016 speech, Orbán decried European policies of integration and tolerance (Timmer, Sery, Connable \& Billinson, 2018). "Europe is not free," he asserted, "Because freedom begins with speaking the truth. Today in Europe it is forbidden to speak the truth... It is forbidden to say that those arriving are not refugees, but that Europe is threatened by migration. It is forbidden to say that tens of millions are ready to set out in our direction. It is forbidden to say that that immigration brings crime and terror to our countries. It is forbidden to point out that the masses arriving from other civilizations endanger our way of life, our culture, our customs, and our Christian traditions" (Orbán, 2016).

This issue may effectively tear Europe apart along an East-West divide. Orbán's opposition to refugee quotas and his rhetoric about accepting only Christians has resonated also among the other three members of the Visegrad-4 (the V4 includes Hungary, the Czech Republic, Poland, and Slovakia). Meanwhile, Hungary's relations with the EU and various member states are victims of Orbán's nationalistic approach. Orbán, from the beginning, 
has been criticized by EU institutions, which have pointed out the undemocratic aspects of his policy changes and accused him of undermining the fundamental principles of the rule of law.
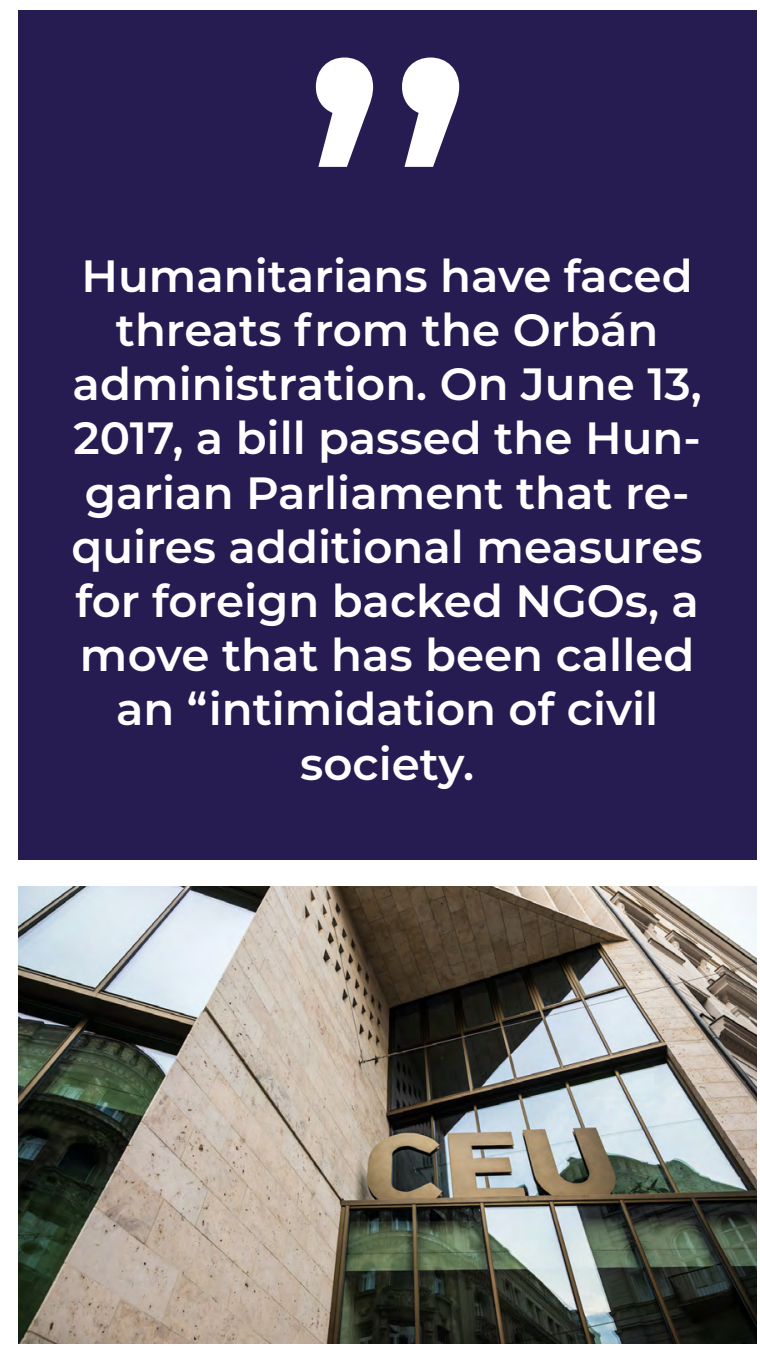

Central European University building or CEU in Budapest on 27 July 2018

Orbán has, from his very first day in office, opposed Brussels' interference in Hungary's internal affairs. He claimed that his country had not opted for feudal relations between Brussels and Budapest when entering the EU. Orbán, however, has made a number of concessions and compromises in his relations with the EU and the European People's Party (Fidesz is a member of the EPP). Ironically, Orbán is a member of the EPP, the EU's center-right bloc. The EPP represents mostly Christian Democrats, whose ancestors were the architects of European integration in the 1950s. According to Jan-Werner Müller, not only are they now tolerating a far-right populist such as Orbán in their midst, but they are also blind to the fact that the Hungarian leader is making a bid for European leadership that could destroy Christian Democracy, and the EU, from the inside (Müller, 2017).

Humanitarians have faced threats from the Orbán administration. On June 13, 2017, a bill passed the Hungarian Parliament that requires additional measures for foreign-backed NGOs, a move that has been called an "intimidation of civil society." NGO workers, humanitarians, and volunteers are also seen as being on the wrong side of public opinion (Timmer, Sery, Connable \& Billinson, 2018). As part of this effort, Orbán and Fidesz have blitzed the Hungarian public with antisemitic attacks on George Soros in recent years, painting him as a behind-the-scenes manipulator bent on seeing his homeland overrun by migrants and refugees. In 2017, Parliament passed a law intended to force the closure of the Central European University, which was founded in 1991 with an endowment from Soros. CEU is technically an American institution. But it was by far Hungary's most prestigious institute of higher education, led by Canadian human rights scholar Michael Ignatieff and boasting a distinguished faculty and 1,440 students from over 100 countries (including 400 students from Hungary). Despite the condemnation of academics around the world and a series of protests, the government went ahead with the plan, and in 2018, CEU announced that it was moving to Vienna (Lendvai, 2019)."It's a warning," Ignatieff told The Washington Post. "Once the rule of law is tampered with, no institution is safe. You can't have academic freedom without the rule of law, and we're in a lawless environment" (Witte, 2018).

Orbán has tried to interpret and present conflicts with internal and foreign actors as part of a pragmatic pattern, as conflicts of interest rather than values. He has portrayed his attacks on the EU as an extension of liberal and socialist complaints, including multinational corporations hurt by EU regulations and taxes. This strategy has been relatively efficient; the Hungarian public did not have clear expectations in regards to the EU. The population perceived the EU not so much as a union of values, i.e. a guarantee of democratic 
and civil rights, but rather as a source of welfare or, even more simply, as a source of subsidies. This made sense: successive governments had rooted their pro-European attitudes in economic arguments (Deák, 2013).

In his State of the Nation address, delivered in Budapest on February 19, 2018, Orbán did not avoid making clear that Hungary's principal danger came from the political leaders of the West: "They want us to adopt their policies: the policies that made them immigrant countries and that opened the way for the decline of Christian culture and the expansion of Islam. They want us to also accept migrants and to also become countries with mixed populations... The true European, they say, 'does not defend such obsolete medieval concepts as homeland and religion.' ... We shall never express solidarity with those European leaders who want to take Europe into a post-Christian and post-national era" (Visegrad Post, Feb. 20, 2018).

In the run-up to the May 2019 elections for the European Parliament, Fidesz undertook a media campaign featuring posters depicting Soros and European Commission President Jean-Claude Juncker that intimated that they had conspired on the EU's migrant policy to threaten Hungarian security. In March, members of the EPP voted overwhelmingly to suspend (but not expel) Fidesz from the EPP. The group established a three-member panel to consider Fidesz's future in the EPP and to evaluate its "respect for the rule of law" (Zalan, 2019). By distancing Hungary from EU values, Orbán also distanced it from liberal democracy itself. Rightfully, in 2015 Freedom House downgraded the country from a "consolidated democracy" to a "semi consolidated democracy" and in 2020 described Hungary as "partly free." Freedom House's Nations in Transit 2020 report reclassified Hungary from a democracy to a transitional or hybrid regime (Freedom House, 2020). 


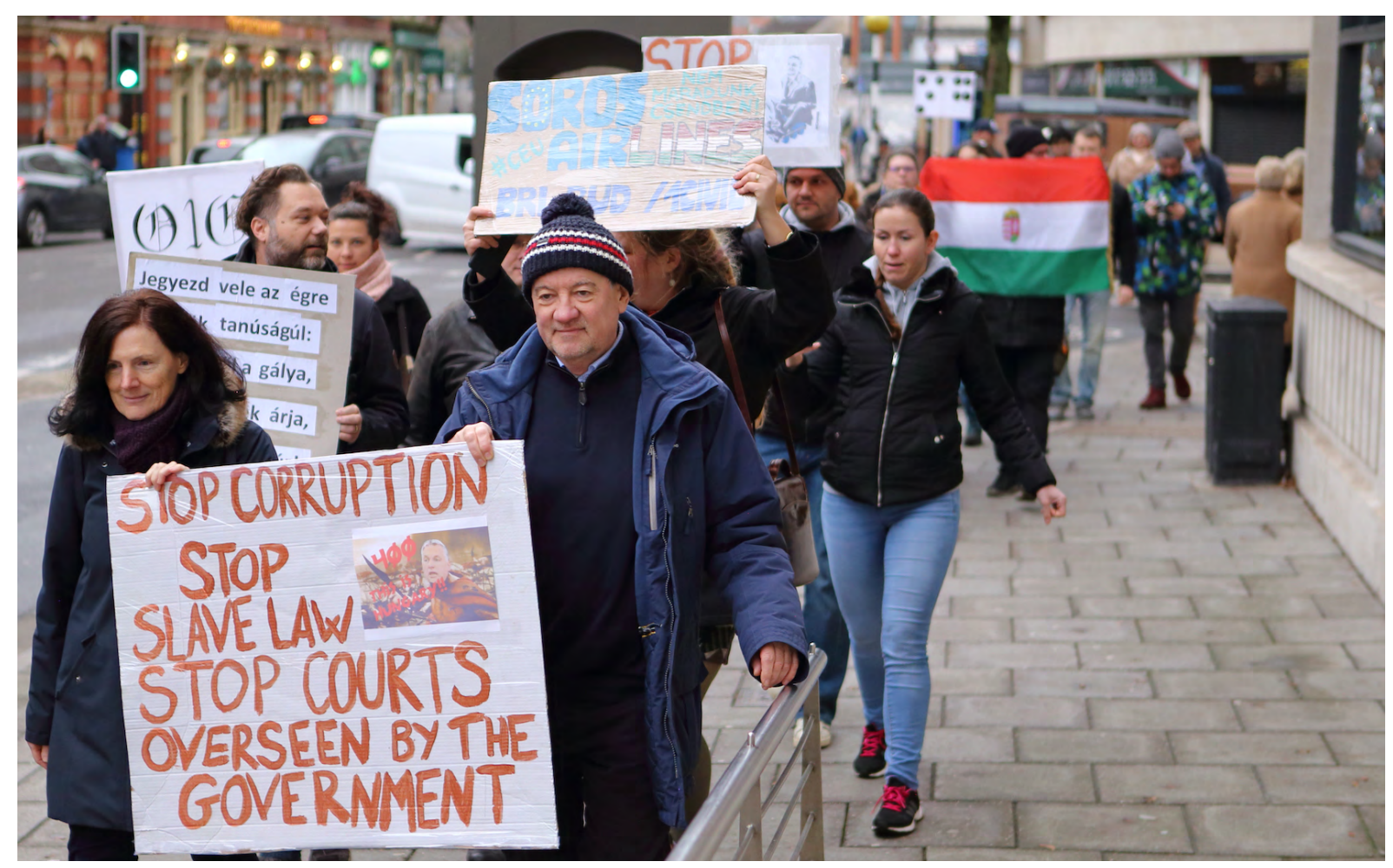

Hungarian people living in Bristol, England marched silently through the streets on December 16, 2018 in a show of solidarity with protesters in Hungary against corruption and a new so-called "slave law".

\section{From “Crony Capitalism” to "Mafia State”}

Viktor Orbán began his political career in the late 1980s, as an outspoken anti-communist and pro-market reformer (Fabry \& Sandbeck, 2019). Following Fidesz's landslide victory in the 2010 general elections, the UK's Financial Times expressed cautious optimism regarding Hungary's prospects, noting that "investors had favored a decisive Fidesz victory in the belief that a strong mandate would allow it to institute sweeping reforms including tackling the country's unwieldy bureaucracy" (Bryant, 2010). However, less than three months later, cautious optimism had given way to the astonishment and stern criticism as the same newspaper scolded Orbán's decision to walk out from negotiations with the IMF, labeling him a "maverick" and "populist" (Financial Times, July 20, 2010).

Orbán, who described the election victory as a "revolution in the polling booths," has changed the "old Republic" dramatically. Not only have fundamental laws been rewritten, including the Constitution itself, but a new, "unorthodox" economic policy has been launched, with milestones like the forced nationalization of private pension funds and the excessive taxation of multinational companies in some selected sectors (Fabry \& Sandbeck, 2019). An economically activist state has been a cornerstone of Orbán's political discourse since at least 2010. In his opinion, only such a state can enforce the public interest against private interests and guarantee the primacy of the national interest against the "supranational elite" (Illés, Körösényi \& Metz, 2018).

Still, in many ways, the basic pattern of Orbán's economic mindset has been obviously neoconservative: the introduction of a new income tax, the liberalization of the labor market, and tightening the eligibility for social benefits (Deák, 2020). Such moves have led many commentators to describe the Orbán regime's economic policies as "Orbánonomics," which represents a Hungarian form of "economic patriotism" (Johnson and Barnes, 2015). Paradoxically, such views echo official propaganda in Budapest. 
In the light of "gulash capitalist" attitudes in the previous decades under sui generis communism, Hungarians' main expectations from the transition under the Orbán administration were economic rather than political. Hungarians wanted welfare much more than freedom (Deák, 2020). Despite Hungary being hit hard by the Great Recession, with economic output contracting by 6.7 percent in 2009 (worse than the EU average of -4.4 percent), many people did not expect their lives to be personally impacted. The impact of the crisis was aggravated by the Hungarian economy's dependence on Western markets (Fabry \& Sandbeck, 2019), which were also in a deep crisis.

As the economy hit the wall, many borrowers were forced to sell their homes or cars, while others faced hefty hikes in mortgage payments. Nevertheless, the belief in upcoming economic growth was strong; thus, Orbán refrained from further cooperation with the International Monetary Fund (IMF) in July 2010 because of the EU's demands for austerity measures as a condition for a $\$ 25.1 \mathrm{bn}$. bailout package. This package was designed to save the country from defaulting on the massive debt accumulated by the Orbán government's predecessors (Rydliński, 2018). The move led to a depreciation of the forint and eventually resulted in Hungarian bonds being downgraded to "junk" status. Despite these setbacks, Orbán stood firm, proclaiming that Hungary "would not accept diktats" from the IMF and the EU in the future, claiming that they are "not our bosses" (Than, 2010).

However, the second round of the economic crisis in the autumn of 2011 dried up Hungary's financial markets. Orbán had to suffer the humiliation of asking for the IMF's help again. Hungary slipped back into recession in 2012. The level of investments remained at a historical low, while the interest rates were almost at 2009 levels. Orbán's rhetoric about "war against the debt" also failed to bring any concrete results (Deák, 2020). When Hungary paid off its remaining bailout debt ahead of schedule, the government called for the IMF to close its Budapest office in August 2013 (Rydliński, 2018).

The Orbán regime has been criticized for its decision to re-nationalize the country's private pension system, which is worth more than $\$ 14$ billion, as well as parts of the energy sector. It has also been criticized for its attempts to reorient the Hungarian economy towards China, Russia, India, and the Middle East. According to former Bulgarian Finance Minister Simeon Djankov, Orbán's economic policies are moving Hungary towards "centrally planned capitalism, like the economic development model pursued in Russia and Turkey" (Djankov, 2015). To achieve this framework, virtually all segments of state-society relations underwent sweeping changes. Declaring Western liberalism and individualism alien to a country with an authoritarian history and collectivist political culture, Orbán called for a strong centralized and paternalist state and emphasized that the new Hungarian state should be "labor-based" (Buzogány, 2017).

In the field of state-market relations, this meant a strong orientation towards stateled economic nationalism, with Orbán declaring his intent to "build a country in which foreign banks and bureaucrats are not telling us what to do." The Hungarian government also made efforts to re-acquire shares lost during the excessive privatization rounds of the 1990s in the sensitive banking, telecommunication, public utilities, and energy sectors and introduced "crisis-taxes" on mostly foreign-owned retailers and financial

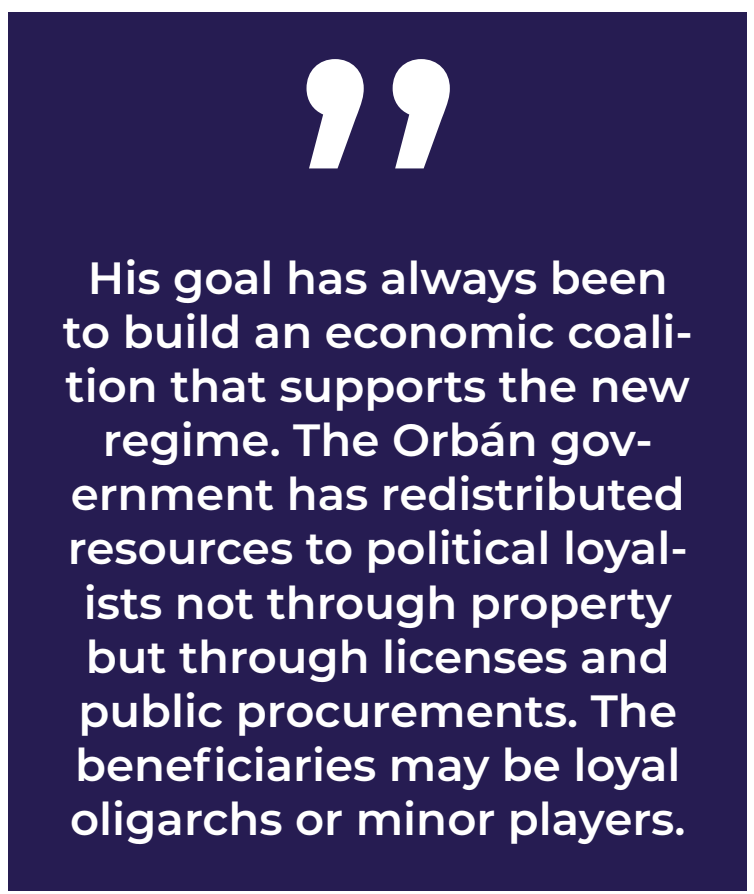


services. The government's self-termed "unorthodox" economic policy has often evoked the term "freedom fight" (szabadságharc), as it is aimed at reducing external involvement and strengthening the middle class (Buzogány, 2017).

According to Orbán and his supporters, the aim of these measures is to "boost the competitiveness" of the Hungarian economy, strengthen the national bourgeoisie, and promote a "work-based society" that is supposed to create one million new jobs by 2020. However, as detailed by numerous studies, the Orbán regime's economic policies have been characterized by systematic "cronyism" and have relentlessly benefitted the top sections of the national bourgeoisie (increasingly a synonym for loyal Fidesz politicians and oligarchs), while failing to improve financial conditions for ordinary Hungarians (Magyar, 2016). This is not surprising: such cronyism has always been part of Orbán's strategy to create a socioeconomic elite that prospers from ties to Fidesz. Under his watch, the process of awarding government contracts has been corrupted to an astonishing degree, almost exclusively to the benefit of Fidesz-connected businesses (Lendvai, 2019).

The goal has always been to build an economic coalition that supports the new regime (Orbán, 2017). The Orbán government has redistributed resources to political loyalists not through the property but through licenses and public procurements. The beneficiaries may be loyal oligarchs (for instance, in the media), or minor players (for instance, in the case of the introduction of a state monopoly and the distribution of new licenses for tobacco sales) (Illés, Körösényi \& Metz, 2018). In early December 2016, the Hungarian government withdrew from the Open Government Partnership (OGP), a multilateral initiative to promote transparency, empower citizens, fight corruption, and harness new technologies to strengthen governance (Novak, 2017). Meanwhile, Transparency International has reported that in 2018, about 40 percent of public procurements in Hungary featured only one bidder (The Brussels Times, 2020).

Balint Magyar has called Orbán's Hungary "a post-communist mafia state, led not by a party, but by Prime Minister Viktor Orbán's political-economic clan" in which Orbán acts as a modern-day Padrino, who uses his personal authority to promote his own economic interests and those of his actual and "adopted" family members, i.e. "oligarchs" who use their connections with the regime to accumulate their own wealth (Magyar, 2016; Fabry \& Sandbeck, 2019). A sense of impunity has fueled this crony capitalism, as Fidesz has hollowed out law enforcement and judicial bodies that would normally investigate and prosecute such misconduct (Lendvai, 2019).

In 2016, the Hungarian opposition claimed that Orbán had a $\$ 750$ million fortune (the Orbán government categorically denies these charges) (Sammon, 2019). However, there are many highly visible signs that "friends" of Orbán thrive under his governance. For instance, a football stadium with 3,800 seats was built in Orbán's birth village, which has a total population of 1,700; a toy train runs between the two parts of the village, transporting tourists to the stadium. As another example, Orbán's neighbor, Lorinc Meszaros, went from being a humble gas plumber to the second wealthiest man in Hungary in the span of 12 years. While some say Meszaros is a straw man for the Prime Minister, Orbán claims that his neighbor is simply a very good businessman. Recently, Orbán's son-in-law, Istvan Tiborcz, also became involved in the business. He started off installing street bulbs in municipalities led by mayors from Orbán's party, and at present, he is rapidly extending his business to hospitality (Zsuzsanna, 2019).

According to an article by David Csik, Laszlo Gulyas, and George Kampis, discussion of corruption in the Hungarian media seems to be endless. Most press articles attempt to track the movements of public funds by tracing the connections between oligarchs and politicians. The authors identified Peter Kiss, Zoltan Varga, Antal Nagy, Marton Szabo, Janos Bertalan, Zsolt Nyerges, Lajos Simicska, and Istvan Töröcskei as the eight most influential businessmen of the Fidesz/Orbán business network (Csik, Gulyas, \& Kampis 2015).

Despite all the claims and accusations, Viktor Orbán asserts that he has been a good steward of the Hungarian economy. 
And, according to Paul Lendavi, it is true that under his government, some Hungarians have done very well. Economist Janos Kornai estimates that tens of thousands of Hungarians have enriched themselves by directly or indirectly exploiting ties to the Orbán regime. But despite Orbán's claims to have revived Hungary's economy, the economist Istvan Csillag has shown that without the funds Hungary receives from the $\mathrm{EU}$, which amount to between 2.5 billion and 5 billion euros a year (the equivalent of 2.5 to 5 percent of GDP), the Hungarian economy would collapse. The irony is that even though his country and his political survival depend on EU funds, Orbán delights in thumbing his nose at Brussels, where handwringing over his autocratic abuses of power has not been accompanied by meaningful efforts to rein him in (Lendvai, 2019).

Some worried that Orbán's corruption and nationalist economic policies would lead to massive capital flight, perhaps necessitating an economic Armageddon; this has not materialized. On the contrary, since 2010, the government has signed a number of high-profile "strategic co-operation agreements" with Audi, Coca-Cola, General Electric, Microsoft, Samsung, and Suzuki, amongst others (Magyar, 2016: 172); and in 2016, German car giant Mercedes announced its intention to invest 1 billion euros in order to build a new manufacturing factory in the south-eastern city of Kecskemet (Fabry \& Sandbeck, 2019). 


\section{CONCLUSION}

Since the end of Soviet dominance in 1989, never has the future for the norms and values of liberal democracy seemed so bleak: for tolerance, respect for the importance of fair debate, checked and balanced government, and objectivity and impartiality in media. In the 30 years that have passed since his speech at Imre Nagy's reburial ceremony in 1989, a staggering reversal has taken place, as Viktor Orbán has transformed from one of the most promising defenders of Hungarian democracy into the chief author of its demise.

Orbán and his acolytes disparage those who disagree with them as unpatriotic fearmongers and traitors to their country; government-controlled media outlets play on historical prejudices and ignorance, and the regime continues to blame the EU for its failings and mistakes. Even if the opposition develops more credible leadership in Hungary, it faces a long, hard road ahead. Because Orbán's popularity seems to be stable despite all his missteps: in the election of April 8, 2018, his party received 47.4 percent of the popular vote, and for the third consecutive election managed to grab two-thirds of the legislative seats (Zsuzsanna, 2019).

Viktor Orbán has managed to keep his base by mobilizing them against a series of "enemies." After losing the 2002 election, Orbán organized a solid base of supporters that he could always turn out to rally for him. First, the base protested the Socialist government. There was a strong sense of "us" and "them" in these rallies, where the "them" was the ruling (Socialist) elite with its neoliberal economic and liberal social ideals. The 2008 economic crisis and the leadership crisis in the Socialist Party led to Orbán's supermajority win in 2010. The stage was set for populism. During the economic crisis, the enemy became a mixture of neoliberal economic ideals, global capital, and banks, all of them personified by Ferenc Gyurcsany. Orbán has not stopped finding new foes. The latest enemies are liberal values, liberal education, and liberal arts. Orbán even blames liberal values for Hungary's declining fertility rate (Zsuzsanna, 2019).

One tool that Orbán uses to further his populist ends is the so-called "national consultation." Since 2010, when the government wants to highlight a topic, it sends out to its citizens a questionnaire with a set of loaded questions. To date, there have been six national consultations and they correspond to the phases of Orbán's populism: 2010, on pensions; 2011, on the constitution; 2011 , again, on government spending (including the utility problem); 2012, on the economy; 2015, on immigration and terrorism; and 2017, on "Stop Brussels." As these consultations are not official referendums, it is unclear how to interpret the results, but it seems to be a good tool for mobilizing the rightwing base around a topic while also conveying the government's ideas. In each of these consultations, about 700,000 people sent in answers, which 
shows a rough approximation of the size of Orbán's most dedicated base (Zsuzsanna, 2019).

Orbán's discursive strategy of raising specific policy problems to a more general level, while also dramatizing them and making them more easily comprehensible, is a central part of his strategy to hold onto power. Specific technical policy problems thereby become attached to general normative concepts such as "independence," "liberty," and "sovereignty." One method of legitimization Orbán often uses is to connect a government action to the Hungarian freedom fights of 1848-1849 (against the Habsburgs) and 1956 (against the Soviets). The foreign power in the current scenario is most often "Brussels," which is sometimes explicitly compared to "Vienna and Moscow." A second ploy is to appeal directly to individuals' "sense of justice." Orbán speaks a "neoconservative political language," which employs easily understandable formulations and references to unchanging moral values and which contrasts strikingly with the rather technocratic discourse of the Hungarian Left (Illés, Körösényi \& Metz, 2018).

As Lendvai noted in his article, Orbán has spent his decade in power systematically dismantling the country's democratic institutions, undermining the rule of law, eliminating constitutional checks and balances, hobbling independent media, and building a kleptocratic system that rewards cronies while sidelining critics. His government does not depend on naked oppression. Rather, through the distribution of sinecures, he has assembled an army of devotees, one that extends far beyond the administration, the police, the secret services, and the military.

In late March 2020, as the deadly coronavirus pandemic began to claim lives in Hungary, Parliament passed a bill that gave Orbán the emergency power to rule by decree, ostensibly to better address the health crisis confronting the country. The law, passed by the Fidesz-controlled Parliament over the strenuous objections of the opposition, suspended elections, mandated stringent penalties for spreading false news, and contained no end for Orbán's expanded powers. "When this emergency ends, we will give back all powers, without exception," Orbán promised the legislators (Kakissis, 2020); but critics argued that he was simply using the crisis as an excuse to extend his authoritarian reach. "This bill would create an indefinite and uncontrolled state of emergency and give Viktor Orbán and his government carte blanche to restrict human rights," said Dávid Vig, Amnesty International's Hungary director. "This is not the way to address the very real crisis that has been caused by the Covid-19 pandemic" (Walker \& Rankin, 2020).

While racist, nationalist, and authoritarian ideas are on the rise throughout Europe and in other parts of the world (Leplat, 2015), for many, the Orbán regime represents a qualitative shift from these examples in that its drift towards the far-right is not merely rhetorical, but also includes a highly conscientious strengthening of state power and the ideological apparatuses of the state; this consolidation of power has happened along the lines that Nic- 
os Poulantzas (1978: 203-250, 2008: 294-322) identified with "authoritarian statism." According to Poulantzas, authoritarian statism is characterized by the decline of parliamentary democracy, increased power of the executive branch and the state bureaucracy, and the insulation of decision-making from democratic oversight (Fabry \& Sandbeck, 2019). However, the damage Orbán has inflicted on Hungary is not limited to its government institutions and economy. He has also degraded the country's political culture by infusing it with forms of xenophobia, racism, and nationalism that could once be found only on the margins of society. Orbán has long toyed with such themes, and since the 2015 refugee crisis, they have become central parts of his political identity (Lendvai, 2019).

Today, Hungary could be defined as, at best, an "illiberal democracy" - a term Orbán has used numerous times to describe his vision for the country. Others argue that the country has left democratic governance behind altogether and is now a crude autocracy. Orbán is also personally described by his critics as "irredentist," "right-wing populist," "authoritarian," "autocratic," and "Putinist." He's also been called a "strongman" and a "dictator." American senator John McCain even called Orbán "a neofascist dictator." (Sammon, 2019). However, as Philip Stephens wrote, Orbán seems to imagine himself a pocket-sized version of Russia's President Vladimir Putin (Stephens, 2017). We should accept that Orbán has played his hand with great skill, outmaneuvering his opponents and tightening his clutch on power. He makes no secret of his plans to rule the country for the foreseeable future. "I will remain in politics for the coming 15 to 20 years," he told a German magazine in 2016. "Maybe in the front row, maybe in the third. Exactly where will be decided by the voters" (Lendvai, 2017). 


\section{REFERENCES}

(1994). Parliamentary election results in Hungary. Hungary Parliamentary Chamber: Orszaggyules. 1994. http://archive.ipu.org/parline-e/reports/arc/2141_94.html (accessed on May 14, 2020).

(1998). Parliamentary election results in Hungary. Hungary Parliamentary Chamber: Orszaggyules. 1998. http://archive.ipu.org/parline-e/reports/arc/2141_98.html (accessed on May 14, 2020).

(2010). Hungary blunders (2010) Financial Times, July 20, 2010, https://www.ft.com/content/65b9bf9e-9363-11df-bb9a-00144feab49a (accessed on May 19, 2020).

(2014). Speech at Băile Tuşnad. Budapest Beacon, July 26. http://budapestbeacon. com/public-policy/full-text-of-viktor-orbans- speech-at-baile-tusnad-tusnadfurdo-of-26-july-2014/10592.

_. (2014). "Viktor Orban.” New Internationalist, (477), 41.

(2016). "Hungary PM claims EU migrant quota referendum victory," BBC, Oct. 3, 2016. https://www.bbc.com/news/world-europe-37528325 (accessed on May 16, 2020).

(2016). Speech by Prime Minister Viktor Orbán on 15 March. http://www.kormany.hu/en/ the-prime-minister/the-prime-minister-s- speeches/speech-by-prime-minister-viktor-orban-on-15-march

(2017). "Hungary: container camp bill is flagrant violation of international law," Amnesty International, March 7, 2017, https://www.amnesty.org/en/latest/news/2017/03/hungary-container-camp-bill-is-flagrant-violation-of-international-law/ (accessed on May 19, 2020).

(2017). Prime Minister Viktor Orbán's speech at the 28th Bálványos summer free university and student camp, 22July. Available at: http://www.kormany.hu/en/the-prime-minister/the-prime-minister-s-speeches/viktor-orban-s-speech-at-the-28th-balvanyos-summeropen-university-and-student-camp (accessed on May 21, 2020).

. (2018). "The West will fall, as Europe is occupied without realising it," said Viktor Orbán. "Christianity is the last hope" - FULL SPEECH (Viktor Orbán's "State of the Nation" address, 18 February 2018, Budapest), Visegrad Post, Feb. 20, 2018, https://visegradpost.com/ en/2018/02/20/the-west-will-fall-as-europe-is-occupied-without-realising-it-said-viktor-orban-christianity-is-the-last-hope-full-speech/ (accessed on May 19, 2020). (US).

(2018). "Orban sceptics; Hungary." The Economist, vol. 428, no. 9109, 15 Sept. 2018, p. 61

_. (2018). "PM Orbán attends Turkish President Recep Tayyip Erdogan's inauguration ceremony in Ankara," About Hungary, July 10, 2018, http://abouthungary.hu/news-in-brief/ pm-orban-attends-turkish-president-recep-tayyip-erdogans-inauguration-ceremony-in-ankara/ (accessed on May 20, 2020).

_. (2019). "Hungary depriving asylum seekers of food - Council of Europe," BBC, May 21, 2019, https://www.bbc.com/news/world-europe-48336590 (accessed on May 21, 2019).

(2019). "Xi meets individually with leaders at forum," China Daily, April 26, 2019. http://www.chinadaily.com.cn/a/201904/26/WS5cc17376a3104842260b8605_8.html (accessed on May 20, 2020). 
. (2020). World Press Freedom Index, Reporters Without Borders (RSF), https://rsf.org/en/ ranking_table (accessed on May 17, 2020).

. (2020). Global Freedom Status, Freedom House, https://freedomhouse.org/explore-the-map?type=fiw\&year=2020(accessed on May 18, 2020).

_. (2020). "Transparency International clashes with Hungary on corruption index," The Brussels Times, Jan. 28, 2020. https://www.brusselstimes.com/all-news/eu-affairs/92292/ transparency-international-clashes-with-hungary-on-corruption-index/ (accessed on May 18, 2020).

_. (2020). "Viktor Orbán," Britannica Online Academic Edition, (2020). Encyclopædia Britannica Inc.

Batory A. (2015). "Populists in Government? Hungary's 'system of national cooperation'." Democratization, 23(2): 283-303.

Bayer, J., 2013. "Emerging anti-pluralism in new democraciesdthe case of Hungary." Osterreichische Zeitschrift fur Politikwissenschaft, 42 (1), 95-110.

Bellamy R. (2007). Political Constitutionalism: A Republican Defence of the Constitutionality of Democracy. Cambridge: Cambridge University Press.

Beauchamp, Zack. (2018). "Hungary just passed a 'Stop Soros' law that makes it illegal to help undocumented migrants," Vox, Jun. 22, 2018, https://www.vox.com/policy-and-politics/2018/6/22/17493070/hungary-stop-soros-orban (accessed on May 19, 2020).

Bienvenu, Helene. 2016. "Newspaper closes in Hungary, and Hungarians see government's hand." The New York Times, October 11, 2016. https:/www.nytimes.com/2016/10/12/world/europe/hungary-newspaper-nepszabadsag.html (accessed on May 19, 2020).

Buckley, N. \& Foy, H. (2016). "Orban and Kaczynski vow 'cultural counter-revolution' to reform EU." Financial Times,7 September 2016.

Buzogány, A. (2017). "Illiberal democracy in Hungary: Authoritarian diffusion or domestic causation?" in: Democratization: Clusters of Authoritarian Diffusion and Cooperation: The Role of Interests vs. Ideology? Guest Editors: André Bank and Kurt Weyland, 24(7), 13071325.

Bryant, C. (2010). "Hungary's center-right in landslide victory." Financial Times, 25 April 2010.

Congdon, Lee. (2018). "Viktor Orban and the Hungarian Resistance: The rise of a populist government in Hungary terrifies the EU and all enemies of national sovereignty." Modern Age, 60(4), 15.

Csik, D., Gulyás, L., \& Kampis, G. (2015). Business Networks. An Analysis of Influential Businessmen within the Network of the FIDESZ Party in Hungary. Procedia Computer Science, 66(C), 247-256.

Csillag T., Szelenyi I. (2015). "Drifting from liberal democracy: Neo-conservative ideology of managed illiberal democratic capitalism in post-communist Europe." Intersections. (1): 1848.

Deák, András. "Hungarian Dances — the Origins and the Future of Viktor Orban's Revolution." Lithuanian Annual Strategic Review 11.1 (2013). 145-68.

Djankov, S. (2015). Hungary Under Orbán: Can Central Planning Revive Its Economy? (Policy Brief No. PB15-11). Washington, DC: Peterson Institute for International Economics. 
Fabry, A., \& Sandbeck, S. (2019). "Neoliberalism, crisis and authoritarian-ethnicist reaction: The ascendancy of the Orbán regime." Competition \& Change, 23(2), 165-191.

Haraszti, M. (2015). "Behind Viktor Orbán's War on Refugees in Hungary." New Perspectives Quarterly, 32(4), 37-40.

Howden, Daniel. 2016. "The manufacture of hatred: Scapegoating refugees in central Europe." Refugees Deeply, December 14, 2016, https://www.newsdeeply.com/refugees/ articles/2016/12/14/the-manufacture-of-hatred-scapegoating-refugees-in-central-europe (accessed on May 17, 2020).

Huysmans J. (2000). The European Union and the securitization of migration. JCMS: Journal of Common Market Studies38(5): 751-777.

Illés, G., Körösényi, A., \& Metz, R. (2018). "Broadening the limits of reconstructive leadership: Constructivist elements of Viktor Orbán's regime-building politics." The British Journal of Politics and International Relations, 20(4), 790-808.

Johnson, J. \& Barnes, A. (2015). "Financial nationalism and its international enablers: the Hungarian experience," Review of International Political Economy, 22(3): 535-569.

Kakissis, Joanna. (2020). "New Law Gives Sweeping Powers To Hungary's Orban, Alarming Rights Advocates," NPR,March 30, 2020, https://www.npr.org/sections/coronavirus-live-updates/2020/03/30/823778208/new-law-gives-sweeping-powers-to-hungarys-orban-alarming-rights-advocates (accessed on May 18, 2020).

Kornai, J., (2015). "Hungary's U-Turn: retreating from democracy." Journal of Democracy. 26 (3), 34-48.

Kovacs, K. \& Toth, G.A., (2011). "Hungary's constitutional transformation." European Consititutonal Law Review. 7, 183-203.

Lendvai, Paul. (2019). "The Transformer: Orban's Evolution and Hungary's Demise", Foreign Affairs, 98(5), pp. 44-54.

Lendvai, Paul. (2017). Orbán: Hungary's Strongman, Oxford University Press, s. 230.

Leplat, F. (ed). (2015). The Far Right in Europe. London: Resistance Books.

Lyman, R. (2015). "Hungary seals border with Croatia in migrant crackdown." The New York Times, 16 October 2015.

Magyar, B. (2016). Post-Communist Mafia State: The Case of Hungary. Budapest: CEU Press.

Metz R. (2017). Határok nélkül? Orbán Viktor és a migrációs válság. In: Körösényi A (ed.)

Viharban Kormányozni. Politikai Vezetők Válsághelyzetekben. Budapest: MTA TK PTI, pp.240-264. Available at: http://politologia.tk.mta.hu/hu/viharban-kormanyozni (accessed on December 5, 2017).

Jan-Werner Müller. (2017). “Viktor Orban is Europe's enemy within.” FT.com, Apr 10, 2017.

Novak, Benjamin. (2017). "Over $40 \%$ of public procurements in Hungary may involve single bidder, says Tl's Gabriella Nagy," The Budapest Beacon, January 5, 2017, https://budapestbeacon.com/over-40-of-public-procurements-in-hungary-may-involve-single-bidder-saystis-gabriella-nagy/ (accessed on May 19, 2020).

"Orban Viktor beszede Nagy Imre es martirtarsai ujratemetesen," Magyar Nemzet, June 16, 2014. 
Poulantzas, N. (1978). State, Power, Socialism. London: Verso.

Poulantzas, N. (2008). The Poulantzas Reader: Marxism, Law, and the State. London: Verso.

Rettman, Andrew, (2014). "US diplomat lashes out at Hungary's Orban," Euobserver, 3 Oct. 2014, https://euobserver.com/foreign/125881 (accessed on May 17, 2020).

Rupnik, J., 2012. "How things went wrong." Journal of Democracy. 23 (3), $132-137$.

Rydliński, B. (2018). "Viktor Orban - First Among Illiberals? Hungarian and Polish Steps Towards Populist Democracy,"OnLine Journal Modelling the New Europe, (26), 95-107.

Sargentini, Judith. (2018). "Report on a proposal calling on the Council to determine, pursuant to Article 7(1) of the Treaty on European Union, the existence of a clear risk of a serious breach by Hungary of the values on which the Union is founded." Committee on Civil Liberties, Justice and Home Affairs, 4.7.2018. https://www.europarl.europa.eu/doceo/document/A-8-2018-0250_EN.html (accessed on May 17, 2020).

Sammon, A. (2019). "Viktor Orbán," New Republic, 250(7/8), p. 5.

Scheppele, K.L., 2014. "Hungary and the End of Politics. How Victor Orban Launched a Constitutional Coup and Created a One-Party State." The Nation. May 6.

Shevchenko, A. (2018). "From a follower to a trendsetter: Hungary's post-Cold War identity and the West." Communist and Post-Communist Studies, 51(1), 63-72.

Spike, Justin. (2017). "'Let's Stop Brussels!': Here is the new National Consultation," The Budapest Beacon, April 3, 2017, https://budapestbeacon.com/lets-stop-brussels-new-national-consultation/ (accessed on May 20, 2020).

Stephens, P. (2017). “Viktor Orban's Hungary crosses to Europe's dark side." FT.com, p. FT.com, Jul 13, 2017.

Szalai, A., Göbl, G. (2016). Securitizing migration in contemporary Hungary: From discourse to practice. Working Paper CEU Center for EU Enlargement Studies, October 20, 2016, https://pds.ceu.edu/events/2016-10-20/securitizing-migration-contemporary-hungary-discourse-practice (accessed on May 15, 2020).

Than, Krisztina. (2010). "Analysis: Hungary risks markets' goodwill with IMF/EU failure," Reuters, July 22, 2010, www.reuters.com/article/us-hungary-imf-analysis-idUSTRE66HOUE20100722 (accessed on May 19, 2020).

Timmer, Andria; Sery, Joseph; Connable, Sean \& Billinson, Jennifer. (2018). "A Tale of Two Paranoids: A Critical Analysis of the Use of the Paranoid Style and Public Secrecy by Donald Trump and Viktor Orbán." Secrecy and Society, February 1, 2018, Vol.1(2).

Walker, Shaun \& Rankin, Jennifer. (2020). "Hungary passes law that will let Orbán rule by decree," The Guardian, March 30, 2020, https://www.theguardian.com/world/2020/mar/30/ hungary-jail-for-coronavirus-misinformation-viktor-orban (accessed on May 19, 2020).

Werkhäuser, N. (2015). "Hungary's Orban criticizes Merkel's 'moral imperialism." Deutsche Welle, 23 September 2015. www.dw.com/en/hungarys-orban-criticizes-merkels-moral-imperialism/a-18736240 (accessed on 19 May 2020).

Witte, Griff. (2018) "The Trump administration tried to save a U.S. university by playing nice with an autocrat. It failed." The Washington Post, November 30, 2018, https://www.washingtonpost.com/world/europe/the-trump-administration-tried-to-save-a-us-university-by- 
playing-nice-with-an-autocrat-it-failed/2018/11/30/f028718a-e831-11e8-8449-1ff263609a31_ story.html (accessed on May 19, 2020).

Zalan, Ester. (2019). "EPP suspends Orban's Fidesz party," Euobserver, March 21, 2019. https://euobserver.com/eu-election/144459 (accessed on May 19, 2020).

Zakaria, Fareed. (2014). "The rise of Putinism," The Washington Post, July 31, 2014, https://www.washingtonpost.com/opinions/fareed-zakaria-the-rise-of-putinism/2014/07/31/2c9711d6-18e7-11e4-9e3b-7f2f110c6265_story.html (accessed on May 19, 2020).

Zsuzsanna, B. (2019). Hungary's Viktor Orban: Populist message, machine methods. Inroads: A Journal of Opinion, (44), 50. 


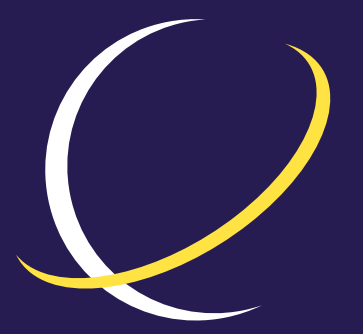

\section{ECPS \\ EUROPEAN CENTER for POPULISM STUDIES}

\section{ABOUT ECPS}

The European Center for Populism Studies (ECPS) is an independent, nonpartisan, nonprofit organization, based in Brussels, for research on and analysis of challenges posed by the resurgence of political populism. ECPS facilitates collaboration among networks of academic experts, practitioners, policymakers, media, and other stakeholders. ECPS offers a platform for the exchange of policy solutions on issues relating to rising populism and provides insights for policy-making and critical analysis to raise broader awareness and engagement through:

\section{Publications}

\section{Academic publications}

Policy reports

White papers

Commentaries

Podcasts and interviews with experts

Events, seminars, workshops, and conferences

\section{Research Programs}

Authoritarianism

Digital Populism

Economics

Environment \& Climate

Extremism \& Radicalisation

\section{Gender}

Human Rights

Foreign Policy

Leadership \& Persona

Migration

\section{ECPS Youth Program}

ECPS Academy 